\title{
Ion-mediated nucleation as an important global source of tropospheric aerosols
}

\author{
F. Yu ${ }^{1}$, Z. Wang ${ }^{2}$, G. Luo ${ }^{1,2}$, and R. Turco ${ }^{3}$ \\ ${ }^{1}$ Atmospheric Sciences Research Center, State University of New York, 251 Fuller Road, Albany, New York 12203, USA \\ ${ }^{2}$ NZC/LAPC, Institute of Atmospheric Physics, Chinese Academy of Sciences, Beijing 100029, China \\ ${ }^{3}$ Dept. of Atmospheric and Oceanic Sciences, Univ. of California, 405 Hilgard Ave, Los Angeles, California 90095, USA
}

Received: 17 August 2007 - Published in Atmos. Chem. Phys. Discuss.: 17 September 2007

Revised: 4 January 2008 - Accepted: 12 April 2008 - Published: 15 May 2008

\begin{abstract}
Aerosol nucleation events have been observed at a variety of locations worldwide, and may have significant climatic and health implications. While ions have long been suggested as favorable nucleation embryos, their significance as a global source of particles has remained uncertain. Here, an ion-mediated nucleation (IMN) mechanism, which incorporates new thermodynamic data and physical algorithms, has been integrated into a global chemical transport model (GEOS-Chem) to study ion-mediated particle formation in the global troposphere. The simulated annual mean results have been compared to a comprehensive set of data relevant to particle nucleation around the globe. We show that predicted annual spatial patterns of particle formation agree reasonably well with land-, ship-, and aircraft-based observations. Our simulations show that, globally, IMN in the boundary layer is largely confined to two broad latitude belts: one in the northern hemisphere $\left(\sim 20^{\circ} \mathrm{N}-70^{\circ} \mathrm{N}\right)$, and one in the southern hemisphere $\left(\sim 30^{\circ} \mathrm{S}-90^{\circ} \mathrm{S}\right)$. In the middle latitude boundary layer over continents, the annual mean IMN rates are generally above $10^{4} \mathrm{~cm}^{-3}$ day $^{-1}$, with some hot spots reaching $10^{5} \mathrm{~cm}^{-3} \mathrm{day}^{-1}$. The zonally-averaged vertical distribution of IMN rates indicates that IMN is significant in the tropical upper troposphere, the entire middle latitude troposphere, and over Antarctica. Comparing the relative strengths of particle sources due to IMN and due to primary particle emissions demonstrates that IMN is significant on a global scale. Further research is needed to reduce modeling uncertainties and to understand the ultimate contribution of freshly nucleated particles to the abundance of cloud condensation nuclei.
\end{abstract}

Correspondence to: $\mathrm{F}$. $\mathrm{Yu}$

(yfq@asrc.cestm.albany.edu)

\section{Introduction}

Atmospheric particles perturb the Earth's energy budget directly by scattering and absorbing radiation and indirectly by acting as cloud condensation nuclei (CCN) and thus changing cloud properties and influencing precipitation. The aerosol indirect radiative forcing is largely determined by the number abundance of particles that can act as cloud condensation nuclei (CCN) (e.g., Twomey, 1977; Albrecht 1989; Charlson et al., 1992). The magnitude of the aerosol indirect radiative forcing is poorly constrained in climate models, and this represents the dominant uncertainty in assessing climate change (NRC, 2005; IPCC, 2007). To reduce the uncertainty in the calculation of aerosol radiative forcing and to improve our prognostic capability of Earth's climate, the key processes controlling the number size distributions of atmospheric aerosols have to be understood and properly incorporated in the large scale models. New particle formation frequently observed throughout the troposphere is an important source of atmospheric $\mathrm{CCN}$ and is one of key processes that need to be accurately represented in future generations of climate models (Ghan and Schwartz, 2007).

Over the past several years, a growing number of studies have focused on new particle formation in the global atmosphere. Spracklen et al. (2006) employed an empirical nucleation rate formulation $\left(J=2 \times 10^{-6} \mathrm{~s}^{-1}\left[\mathrm{H}_{2} \mathrm{SO}_{4}\right]\right.$, where $\left[\mathrm{H}_{2} \mathrm{SO}_{4}\right]$ is the sulfuric acid vapor concentration in $\mathrm{cm}^{-3}$ ) to study the contribution of boundary layer nucleation events to total particle concentrations on regional and global scales. Taking a different approach, Kazil et al. (2006) used monthly-mean $\mathrm{SO}_{2}$ concentrations, a parameterized $\mathrm{OH}$ diurnal cycle, and daily mean temperatures and relative humidities to calculate the formation rates of sulfate aerosol in the marine troposphere (over oceans only), considering neutral and charged nucleation processes involving $\mathrm{H}_{2} \mathrm{SO}_{4}$ and

Published by Copernicus Publications on behalf of the European Geosciences Union. 
$\mathrm{H}_{2} \mathrm{O}$, by applying the box model of Lovejoy et al. (2004) on grids embedded into 4 isobaric surfaces of the troposphere (925, 700, 550, and $300 \mathrm{hPa})$. Lucas and Akimoto (2006), on the other hand, used a 3-D global chemical transport model to evaluate models of binary (Vehkamäki et al., 2002), ternary (Napari et al., 2002), and ion-induced (Lovejoy et al., 2004; Modgil et al., 2005) nucleation.

Lucas and Akimoto (2006) found that the binary nucleation model of Vehkamäki et al. (2002) and ion-induced nucleation model of Lovejoy et al. (2004) predict new particle formation only in the colder upper troposphere. Their simulations also showed that binary nucleation rates based on Vehkamäki et al. (2002) are generally several orders of magnitude higher than the ion-induced nucleation rates based on the parameterization of Lovejoy et al. (2004)'s model. However, recent studies indicate that the BHN model of Vehkamäki et al. (2002) may have overestimated the BHN rates by around three orders of magnitude (Hanson and Lovejoy, 2006; Yu, 2007) and ion-induced nucleation model of Lovejoy et al. (2004) may have underestimated the ion induced nucleation rates by more than two to four orders of magnitude (Yu and Turco, 2008). Given these substantial conflicts in current nucleation model predictions, it appears there is a serious weakness in our ability to determine accurately the relative and absolute contributions of competing nucleation mechanisms to new particle production in the troposphere.

Yu (2006a) utilized a kinetically consistent ion-mediated nucleation model (IMN) to demonstrate that ions can lead to significant particle formation not only in the upper troposphere but also in the lower troposphere (including boundary layer). The role of ions in many boundary layer nucleation events has been recently confirmed by observations of evolving charged cluster distributions exhibiting significant overcharging in the nanometer size range during nucleation events (Vana et al., 2006; Hirsikko et al., 2007; Laakso et al., 2007). Nevertheless, the relative importance of ionmediated nucleation versus neutral nucleation under varying atmospheric conditions remains unresolved (Vana et al., 2006; Iida et al., 2006; Hirsikko et al., 2007; Laakso et al., 2007; Kulmala et al., 2007; Yu and Turco, 2007, 2008). It appears that new nanometer-sized particles are overcharged during more than $90 \%$ of nucleation events sampled during spring 2005 in Hyytiälä, Finland, during the BACCI/QUEST IV field campaign (Laakso et al., 2007). Laakso et al. (2007) followed through with an analytical analysis indicating a relatively small contribution due to ion nucleation. More recently, Kulmala et al. (2007) analyzed multiple-instrument measurements of neutral and charged nanometer-sized cluster concentrations taken in Hyytiälä, Finland in Spring 2006 and concluded that neutral nucleation dominated over ioninduced nucleation under boreal forest conditions. Yu and Turco (2008) extended earlier IMN analyses (Yu and Turco, 2007) to include detailed case studies of six representative nucleation events observed in Hyytiälä. These specific replications showed that, under the general conditions corresponding to most of nucleation event days, the IMN model reasonably reproduces a range of observational parameters, including critical nuclei sizes, size-dependent overcharging ratios, the concentrations of sub-3 $\mathrm{nm}$ stable clusters and $3-$ $6 \mathrm{~nm}$ particles, and the diurnal variations of these particles. The new results thus appear to provide strong support for the IMN mechanism.

The objective of the present paper is to study the significance of the IMN mechanism as a global source of new particles, and to determine the spatial patterns of Earth's nucleation zones. To achieve the objective, the IMN mechanism was integrated into a global chemical transport model (GEOS-Chem). For validation purposes, the simulated results were compared with land-, ship-, and aircraft-based measurements related to particle formation. The model and data used in this study are briefly described in Sects. 2 and 3, respectively. Section 4 presents modeling results and comparisons with measurements. A summary and discussion is given in Sect. 5.

\section{GEOS-Chem model}

To study particle nucleation in the global atmosphere, we include our IMN mechanism in the GEOS-Chem model which is a global 3-D model of atmospheric composition driven by assimilated meteorological observations from the Goddard Earth Observing System (GEOS) of the NASA Global Modeling Assimilation Office (GMAO). Meteorological fields include surface properties, humidity, temperature, winds, cloud properties, heat flux and precipitation. The GEOS-3 data, including cloud fields, have 6-h temporal resolution (3-hour resolution for surface fields and mixing depths), $1^{\circ} \times 1^{\circ}$ horizontal resolution, and 48 vertical sigma levels extending from the surface to approximately $0.01 \mathrm{hPa}$. The horizontal resolution can be degraded and vertical layers merged for computational efficiency. For the results presented in this paper, the GEOS-3 grid with $2^{\circ} \times 2.5^{\circ}$ horizontal resolution and 30 vertical levels was used. The first 15 levels in the model are centered at approximately 10, 50, 100, 200, 330, 530, $760,1100,1600,2100,2800,3600,4500,5500$, and $6500 \mathrm{~m}$ above surface.

The GEOS-Chem model includes a detailed simulation of tropospheric ozone- $\mathrm{NO}_{\mathrm{x}}$-hydrocarbon chemistry as well as of aerosols and their precursors (Park et al., 2004). In addition to sulfate and nitrate aerosols, the model also considers organic and elemental carbon aerosols (Park et al., 2003), dust (Fairlie et al., 2004), and sea salt aerosol (Alexander et al., 2005). Aerosol and gas-phase simulations are coupled through sulfate and nitrate formation, heterogeneous chemistry (Evans and Jacob, 2005), aerosol effects on photolysis rates (Martin et al., 2003), and secondary organic aerosol formation. The ISORROPIA thermodynamic equilibrium model (Nenes et al., 1998) is used to calculate partitioning 
of total ammonia and nitric acid between the gas and aerosol phases. A detailed description of the model (including the treatment of various emission sources, chemistry and aerosol schemes) can be found in the model webpage (http://www. as.harvard.edu/chemistry/trop/geos/index.html).

The sulfur emission in GEOS-CHEM (Park et al., 2004) includes: 1) the fossil fuel and industrial emission (Benkovitz et al., 1996; Bey et al., 2001),2) the gridded monthly aircraft and shipping emissions (Chin et al., 2000), 3 ) the biofuel emission based on the global biofuel $\mathrm{CO}$ emission from Yevich and Logan (2003), 4) the biomass burning emissions from Duncan et al. (2003), 5) the oceanic DMS emission calculated with an empirical formula from Liss and Merlivat (1986), and 6) the volcano emission from the database of Andres and Kasgnoc (1998). In the original version of GEOS-CHEM (v7-03-06), the fossil fuel and industrial emission is obtained by scaling the gridded, seasonally resolved inventory from the Global Emissions Inventory Activity (GEIA) for 1985 (Benkovitz et al., 1996) with updated national emission inventories and fuel use data (Bey et al., 2001). In this study, the $\mathrm{SO}_{2}$ database from EDGAR 3.2, which fully considered the productions of energy, fossil fuel, biofuel, industrial processes, agriculture and waste handling (Olivier, 2001), is used to update the GEOS-CHEM anthropogenic sulfur emission data to year 2002. The global gridded scaling factor is derived according to the historical trend from 1990 to 2000. Due to the uncertainty of the emissions from sporadically erupting volcanoes, we only consider the continuously active volcanoes emission in this study.

\section{Data relevant to atmospheric particle formation}

\subsection{Land based measurements}

New particle formation has been observed extensively at many locations around the globe. Kulmala et al. (2004) provides a comprehensive review of measurements relevant to the formation of particles in ambient atmosphere. All of the cases with defined particle formation rates as listed in Kulmala et al. (2004) are used in this study for comparison. Table 1 gives additional sets of particle formation data published since 2004, which are also considered for comparison in this study.

\subsection{Ship based measurements}

In a number of field campaigns, total concentrations of condensation nuclei $(\mathrm{CN}$, diameter $>\sim 12 \mathrm{~nm})$ and ultrafine condensation nuclei (UCN, diameter $>\sim 3 \mathrm{~nm}$ ) in the surface layer of the ocean were continuously measured with $\mathrm{CN}$ counters during ship cruises. The average particle formation rates at a given day can be estimated based on the change (increase) rates in the $\mathrm{UCN}$ and $\mathrm{CN}$ concentration difference (i.e., $\mathrm{C}_{\mathrm{UCN}}-\mathrm{C}_{\mathrm{CN}}$ ) typically during the morning hours.
Table A1 in Appendix A gives the ship-based particle formation rates we have derived from the measurements obtained during the following field campaigns: RITS94, INDOEX99, ACE-Asia, ACE-2, ACE-1, NAURU99, NEAQS02, and NEAQS04. The original data were obtained from NOAA PMEL Atmospheric Chemistry Data Server (http://saga.pmel.noaa.gov/data/) where more information about the field campaigns can be found. In Table A1 we also include two additional sets of particle formation rates estimated from two published papers (Davison et al., 1996; Koponen et al., 2002).

\subsection{Aircraft based measurements}

Clarke and Kapustin (2002) published a survey of extensive aerosol data collected around the Pacific Basin during a number of field campaigns: Global Backscatter Experiment (GLOBE), First Aerosol Characterization Experiment (ACE-1), and Pacific Exploratory Mission (PEM)-Tropics A and $\mathrm{B}$. The ultrafine condensation nuclei (UCN) counter was used to detect all particles larger than $\sim 3-4 \mathrm{~nm}$. The aircraftbased measurements considered in this study include the total UCN concentrations measured during GLOBE, ACE-1, and PEM-Tropics A and B (data obtained from Kapustin - about 146600 10-second-average data points), as well as data from two more recent field missions: TRAnsport and Chemical Evolution over the Pacific (TRACE-P), and the Intercontinental Chemical Transport Experiment-Phase A (INTEX-A). TRACE-P and INTEX-A (about 100000 10-second-average data points) significantly increased the number of observations for the Northern Hemisphere. TRACE-P and INTEXA measurements were obtained from NASA's Global Tropospheric Experiment (GTE) database website.

\section{Simulations and comparisons with observations}

The nucleation module used in this study is composed of look-up tables of pseudo-steady state nucleation rates under various conditions that are derived by running the detailed IMN model (Yu, 2006a). The current version of the IMN model only considers the binary $\mathrm{H}_{2} \mathrm{SO}_{4}-\mathrm{H}_{2} \mathrm{O}$ system. The tabulated ion-mediated nucleation rates $\left(J_{\mathrm{IMN}}\right)$ depend on the following variables: sulfuric acid vapor concentration, $\left[\mathrm{H}_{2} \mathrm{SO}_{4}\right]\left(\mathrm{cm}^{-3}\right)$; relative humidity, $\mathrm{RH}$; temperature, $T(\mathrm{~K})$; ionization rate, $\mathrm{Q}$ (ion-pairs $\mathrm{cm}^{-3} \mathrm{~s}^{-1}$ ); and the local surface area density of pre-existing particles, $\mathrm{S}_{0}\left(\mu \mathrm{m}^{2} \mathrm{~cm}^{-3}\right)$. Thus, $J_{\mathrm{IMN}}=f\left(\left[\mathrm{H}_{2} \mathrm{SO}_{4}\right], \mathrm{RH}, T, \mathrm{Q}, \mathrm{S}_{0}\right)$. In the look-up tables, $T$ ranges from $190 \mathrm{~K}$ to $300 \mathrm{~K}$ with a resolution of $2 \mathrm{~K}$ and RH ranges from $1 \%$ to $99 \%$ with a resolution of $2 \%$. In the sub-table for relatively high $\mathrm{T}$ range $(T \geq 250)$, $\left[\mathrm{H}_{2} \mathrm{SO}_{4}\right]$ ranges from $5 \times 10^{5}-5 \times 10^{8} \mathrm{~cm}^{-3}$ with a resolution of 10 values per decade (geometric), Q ranges from 1.530 ion-pairs $\mathrm{cm}^{-3} \mathrm{~s}^{-1}$ with a resolution of 10 values per decade (geometric), $S_{0}$ ranges from $10-1000 \mu \mathrm{m}^{2} \mathrm{~cm}^{-3}$ with 
Table 1. Measurements of particle formation events in addition to those listed in the review paper by Kulmala et al. (2004). J3 and J10 refer to the "apparent" formation rates of $3 \mathrm{~nm}$ and $10 \mathrm{~nm}$ particles during the nucleation periods, respectively (in $\mathrm{cm}^{-3} \mathrm{~s}^{-1}$ ) (refer to Turco et al., 1998 , for a discussion of apparent nucleation rates).

\begin{tabular}{|c|c|c|c|c|c|c|}
\hline Location & Time period & \# of events & $\mathrm{J} 3$ & $\mathrm{~J} 10$ & Growth rates $(\mathrm{nm} / \mathrm{hr})$ & references \\
\hline $\begin{array}{l}\text { Rochester, USA } \\
\left(43^{\circ} 10^{\prime} \mathrm{N}, 77^{\circ} 36^{\prime} \mathrm{W}\right)\end{array}$ & $12 / 2001-12 / 2003$ & 307 & & 3 & $5-12$ & $\begin{array}{l}\text { Jeong et al., 2004, } 2006 \\
\text { Hopke and Utell, } 2005\end{array}$ \\
\hline $\begin{array}{l}\text { Värriö, Finland }\left(67^{\circ} 46^{\prime} \mathrm{N},\right. \\
\left.29^{\circ} 35^{\prime} \mathrm{E}\right)\end{array}$ & 1998-2002 & 147 & & 0.1 & $0.5-10$ & Vehkamäki et al., 2004 \\
\hline $\begin{array}{l}\text { Sumas Mountain }\left(49^{\circ} 03^{\prime} \mathrm{N} \text {, }\right. \\
\left.122^{\circ} 15^{\prime} \mathrm{W}\right)\end{array}$ & 8/13/2001-9/01/2001 & 5 & 5 & & $5-10$ & Mozurkewich et al., 2004 \\
\hline $\begin{array}{l}\text { Antarctica } \\
\left.11^{\circ} 44^{\prime} \mathrm{E}\right)\end{array}$ & 1/10/1997-2/24/1997 & 14 & & $0.1-0.8$ & & Deshpande and Kamra, 2004 \\
\hline $\begin{array}{l}\text { Pittsburgh, USA }\left(40^{\circ} 26^{\prime} \mathrm{N},\right. \\
\left.79^{\circ} 59^{\prime} \mathrm{W}\right)\end{array}$ & $07 / 2001-06 / 2002$ & 107 & $1-10$ & & & Stanier et al., 2004 \\
\hline $\begin{array}{l}\text { Po Valley, Italy } \\
\left(44^{\circ} 39^{\prime} \mathrm{N}, 11^{\circ} 37^{\prime} \mathrm{E}\right)\end{array}$ & 03/24/2002-08/24/2004 & 304 & $\sim 7$ & & $0.3-22.2$ & $\begin{array}{l}\text { Laaksonen et al., } 2005 \\
\text { Hamed et al., } 2007\end{array}$ \\
\hline $\begin{array}{l}\text { New Deli, Indian }\left(28^{\circ} 35^{\prime} \mathrm{N} \text {, }\right. \\
\left.77^{\circ} 12^{\prime} \mathrm{E}\right)\end{array}$ & 10/26/2002-11/09/2002 & 8 & $\sim 7.3$ & & $11.6-18.1$ & Mönkkönen et al., 2005 \\
\hline $\begin{array}{l}\text { Santa Ana, Mexico }\left(19^{\circ} 11^{\prime} \mathrm{N},\right. \\
\left.98^{\circ} 59^{\prime} \mathrm{W}\right)\end{array}$ & $4 / 10 / 2003-4 / 20 / 2003$ & 2 & $\sim 10$ & & 4.7 & Dunn et al., 2004 \\
\hline $\begin{array}{l}\text { CENICA, Mexico }\left(19^{\circ} 21^{\prime} \mathrm{N},\right. \\
\left.99^{\circ} 04^{\prime} \mathrm{W}\right)\end{array}$ & $5 / 2 / 2003-5 / 11 / 2003$ & 3 & $\sim 4$ & & & Dunn et al., 2004 \\
\hline $\begin{array}{l}\text { Tumbarumba, Australia } \\
\left(35^{\circ} 40^{\prime} \mathrm{S}, 148^{\circ} 15^{\prime} \mathrm{E}\right)\end{array}$ & 2005 & $\sim 100$ & 0.15 & & $1-6.5$ & Suni et al., 2006 \\
\hline $\begin{array}{l}\text { Mukteswar, Himalaya Mt. } \\
\left(29^{\circ} 31^{\prime} \mathrm{N}, 79^{\circ} 39^{\prime} \mathrm{E}\right)\end{array}$ & $3 / 23 / 2006-7 / 7 / 2006$ & 23 & 0.4 & & & Lihavainen et al., 2006 \\
\hline $\begin{array}{l}\text { Anmyeon, } \quad \text { S. } \\
\left(36^{\circ} 22^{\prime} \mathrm{N}, 126^{\circ} 19^{\prime} \mathrm{E}\right)\end{array}$ & $01 / 2005-12 / 2005$ & 24 & 1.5 & & & Lee et al., 2006 \\
\hline $\begin{array}{l}\text { Beijing, China } \\
\left(39^{\circ} 55^{\prime} \mathrm{N}, 116^{\circ} 25^{\prime} \mathrm{E}\right)\end{array}$ & 03/2004-02/2005 & $\sim 170$ & $\sim 1.5$ & & $0.1-13.5$ & $\begin{array}{l}\text { Wehner et al., 2006; } \\
\text { Wu et al., } 2007\end{array}$ \\
\hline $\begin{array}{l}\text { Gosan, S. Korea }\left(33^{\circ} 17^{\prime} \mathrm{N} \text {, }\right. \\
\left.126^{\circ} 10^{\prime} \mathrm{E}\right)\end{array}$ & 03/11/2005-04/08/2005 & $\sim 6$ & $\sim 1.5$ & & & Yum et al., 2006 \\
\hline $\begin{array}{l}\text { Houston, USA }\left(29^{\circ} 54^{\prime} \mathrm{N},\right. \\
\left.95^{\circ} 20^{\prime} \mathrm{W}\right)\end{array}$ & $8 / 22 / 2004-8 / 29 / 2004$ & $\sim 8$ & $\sim 2$ & & & Fan et al., 2006 \\
\hline $\begin{array}{l}\text { Marseille, France }\left(43^{\circ} 19^{\prime} \mathrm{N},\right. \\
\left.5^{\circ} 42^{\prime} \mathrm{E}\right)\end{array}$ & $7 / 1 / 2002-7 / 19 / 2002$ & 4 & $3-5.3$ & & $2-8$ & Petäjä et al., 2007 \\
\hline $\begin{array}{l}\text { Athens, Greece } \quad\left(38^{\circ} 9^{\prime} \mathrm{N},\right. \\
\left.23^{\circ} 45^{\prime} \mathrm{E}\right)\end{array}$ & 6/11/2003-6/26/2003 & 7 & $1.3-6.5$ & & $1.2-9.9$ & Petäjä et al., 2007 \\
\hline $\begin{array}{l}\text { St. Louis, USA }\left(38^{\circ} 36^{\prime} \mathrm{N} \text {, }\right. \\
\left.90^{\circ} 09^{\prime} \mathrm{W}\right)\end{array}$ & $4 / 1 / 2001-5 / 31 / 2003$ & 155 & $8-14$ & & 4.7 & Qian et al., 2007 \\
\hline $\begin{array}{l}\text { Pear River Delta, China } \\
\left(22^{\circ} 36^{\prime} \mathrm{N}, 113^{\circ} 36^{\prime} \mathrm{E}\right)\end{array}$ & $10 / 3 / 2004-11 / 5 / 2004$ & 4 & $4-6$ & & $6.8-13.8$ & Gong et al., 2008 \\
\hline
\end{tabular}

a resolution of 5 values per decade (geometric) plus one point at $\mathrm{S}_{0}=1 \mu \mathrm{m}^{2} \mathrm{~cm}^{-3}$. In the sub-table for relatively low $T$ range $(T<250 \mathrm{~K}),\left[\mathrm{H}_{2} \mathrm{SO}_{4}\right]$ ranges from $5 \times 10^{5}-$ $5 \times 10^{7} \mathrm{~cm}^{-3}$ with a resolution of 10 values per decade (geometric), $\mathrm{Q}$ ranges from $5-50$ ion-pairs $\mathrm{cm}^{-3} \mathrm{~s}^{-1}$ with a resolution of 10 values per decade (geometric), $\mathrm{S}_{0}$ ranges from $10-100 \mu \mathrm{m}^{2} \mathrm{~cm}^{-3}$ with a resolution of 5 values per decade (geometric) plus one point at $\mathrm{S}_{0}=1 \mu \mathrm{m}^{2} \mathrm{~cm}^{-3}$. At given values of $\left[\mathrm{H}_{2} \mathrm{SO}_{4}\right], T, \mathrm{RH}, \mathrm{Q}$, and $\mathrm{S}_{0}, J_{\text {IMN }}$ can be decided using the look-up tables with an efficient multiple-variable interpolation scheme similar to the one given in $\mathrm{Yu}$ (2006b) except that the number of variables increases from 3 to 5 . The differences between the interpolated values of $J_{\text {IMN }}$ and those corresponding values calculated with full IMN model are generally within a few percentages.

In the current version of GEOS-Chem (v7-03-06), $\mathrm{H}_{2} \mathrm{SO}_{4}$ vapor concentration $\left(\left[\mathrm{H}_{2} \mathrm{SO}_{4}\right]\right)$ is not explicitly resolved (all $\mathrm{H}_{2} \mathrm{SO}_{4}$ gas produced is moved to particulate phase instanta- neously). We have modified the code and now $\left[\mathrm{H}_{2} \mathrm{SO}_{4}\right]$ is a prognostic variable. The change of $\left[\mathrm{H}_{2} \mathrm{SO}_{4}\right]$ is determined by $\mathrm{d}\left[\mathrm{H}_{2} \mathrm{SO}_{4}\right] / \mathrm{dt}=\mathrm{P}-\mathrm{CS} \times\left[\mathrm{H}_{2} \mathrm{SO}_{4}\right]$, where $\mathrm{P}$ is the production rate of $\left[\mathrm{H}_{2} \mathrm{SO}_{4}\right]$ from gas phase chemistry (mainly $\mathrm{OH}+\mathrm{SO}_{2}$ ) and $\mathrm{CS}$ is the condensation sink for $\mathrm{H}_{2} \mathrm{SO}_{4}$ gas associated with the condensation of $\mathrm{H}_{2} \mathrm{SO}_{4}$ vapor on pre-existing particles. The ability of the GEOS-Chem model to predict the global $\mathrm{OH}$ concentration field has been evaluated independently by Bey et al. (2001). CS and $\mathrm{S}_{0}$ are calculated from the particle mass predicted in the GEOS-Chem and assumed particle sizes. The transport and deposition of $\mathrm{H}_{2} \mathrm{SO}_{4}$ vapor are also taken into account in the model. The global ionization rates due to cosmic rays are calculated based on the schemes given in Usoskin and Kovaltsov (2006) and the contribution of radioactive materials from soil to ionization rates is parameterized based on the profiles given in Reiter (1992). We run the GEOS-Chem coupled with nucleation module for one year from $07 / 01 / 2001$ to $06 / 30 / 2002$. The 
time step for transport is 15 min and for chemistry (and nucleation) is $30 \mathrm{~min}$. Figure 1 presents the simulated horizontal (averaged in seven lowest model layers representing the boundary layer) and vertical (zonal-averaged) spatial distributions of annual mean $\mathrm{SO}_{2}$ concentration, condensation sink, and $\left[\mathrm{H}_{2} \mathrm{SO}_{4}\right]$. The calculations of $\mathrm{CS},\left[\mathrm{H}_{2} \mathrm{SO}_{4}\right]$, and hence nucleation rates are only limited to grid boxes within GEOS-Chem's annual mean tropopause.

Figures $1 \mathrm{a}$ and $1 \mathrm{~b}$ shows that the high $\mathrm{SO}_{2}$ concentration zones are generally confined to source regions. The annual mean $\mathrm{SO}_{2}$ surface layer concentrations in large areas of eastern United States, Europe, eastern China, Indian, Mexico, and Chile are above $1 \mathrm{ppb}$ with some hot spots above $3 \mathrm{ppb}$. Vertically, high $\mathrm{SO}_{2}$ concentration (zonal average $>0.1 \mathrm{ppb}$, note the difference in the scale of Fig. 1a and b) zone can reach up to around $700 \mathrm{hpa}(\sigma=\sim 0.7)$ with the highest concentration limited to below 800 hpa in the northern hemisphere. The relatively low $\mathrm{SO}_{2}$ concentration in middle and upper tropical $\left(\sim 20^{\circ} \mathrm{S}-30^{\circ} \mathrm{N}\right)$ troposphere is probably due to relatively weak $\mathrm{SO}_{2}$ sources and high scavenging rate associated with convection and precipitation. The relatively high $\mathrm{SO}_{2}$ concentration over Antarctica is mainly associated with DMS emission near the Antarctic coast. The extension of high $\mathrm{SO}_{2}$ zone from surface up to $300 \mathrm{hpa}$ around latitude of $30^{\circ} \mathrm{S}$ is associated with mountain uplifting of anthropogenic $\mathrm{SO}_{2}$ emission in Chile and direct injection of $\mathrm{SO}_{2}$ into middle troposphere from the continuously active volcano Lascar in Chile $\left(2400 \mathrm{Mg}-\mathrm{SO}_{2} / \mathrm{day}, 23.32^{\circ} \mathrm{S}, 67.44^{\circ} \mathrm{W}\right.$, elevation $5.6 \mathrm{~km})$.

It is clear from Fig. 1c and d that large areas of eastern and southern Asia, western Europe, eastern United States, southern America, and Africa have high CS associated with anthropogenic emission, biomass burning, and dust emission. Vertically, the high CS zone centered around $30^{\circ} \mathrm{N}$ extends to $\sim 600-700 \mathrm{hpa}$. In contrast to Artic region which is influenced by regional transport of particle pollutants, the CS around Antarctica is very low. In addition to sea salt emission, the CSs over oceans adjacent to continents are significantly affected by transported particles. The concentration of $\mathrm{H}_{2} \mathrm{SO}_{4}$ vapor (Fig. 1e, f) is determined by its production rate (mainly controlled by $\mathrm{SO}_{2}$ and $\mathrm{OH}$ concentration) and loss rate (condensation sink). The highest $\left[\mathrm{H}_{2} \mathrm{SO}_{4}\right]$ regions are confined to areas of high $\mathrm{SO}_{2}$ concentration, high annual irradiance flux, and low CS. In regions of higher $\mathrm{SO}_{2}$ as well as higher CS, it appears that the increased production dominates and thus $\left[\mathrm{H}_{2} \mathrm{SO}_{4}\right]$ is generally higher. Vertically, $\left[\mathrm{H}_{2} \mathrm{SO}_{4}\right]$ generally decreases with altitude due to the more rapidly decrease of $\mathrm{SO}_{2}$ with altitude. The relatively high $\left[\mathrm{H}_{2} \mathrm{SO}_{4}\right]$ in tropical upper troposphere is due to the very lower CS calculated in the model. It should be noted that many factors (including sub-grid processes) may influence the accuracy of $\left[\mathrm{H}_{2} \mathrm{SO}_{4}\right]$ simulated in global models such as GEOS-Chem. Further research is needed to reduce the uncertainties in $\left[\mathrm{H}_{2} \mathrm{SO}_{4}\right]$ calculations by comparing the modeled values with observed ones at selected locations and time pe- riods where and when data are available. Figure 2 shows the predicted annual mean nucleation rates averaged within the seven lowest model layers $(\sim 0-930 \mathrm{~m})$ representing the atmospheric boundary layer. Also given for comparison are average particle formation rates derived from various surfacebased measurements (refer to Sect. 3 for details). Observed nucleation events typically last for $\sim 3 \mathrm{~h}$ a day (e.g., Birmili et al., 2003; Laakso et al., 2004; Stanier et al., 2004; Qian et al., 2007), and thus an observed average nucleation rate of 1 particle $\mathrm{cm}^{-3} \mathrm{~s}^{-1}$ is equivalent to roughly $10^{4}$ particles $\mathrm{cm}^{-3} \mathrm{day}^{-1}$. We have used this equivalence to cross-calibrate the color bars in the figure.

Our simulations show that, globally, nucleation in the boundary layer is largely confined to two broad latitude belts: one in the northern hemisphere $\left(\sim 20^{\circ} \mathrm{N}-70^{\circ} \mathrm{N}\right)$, and one in the southern hemisphere $\left(\sim 30^{\circ} \mathrm{S}-90^{\circ} \mathrm{S}\right)$. In the boundary layer, nucleation rates over continents are generally much higher than those over oceans. In the middle latitude boundary layer over continents, the annual mean new particle production rates are generally above $10^{4} \mathrm{~cm}^{-3} \mathrm{day}^{-1}$, with some hot spots reaching $10^{5} \mathrm{~cm}^{-3} \mathrm{day}^{-1}$. Over middle latitude oceanic boundary layer, the annual mean new particle production rates are generally below $2500 \mathrm{~cm}^{-3} \mathrm{day}^{-1}$. As can be seen from the high nucleation rates in the vicinity of anthropogenic sources and spatial patterns of $\mathrm{SO}_{2}$ concentrations, most boundary layer nucleation events in the northern hemisphere (except over remote ocean areas, and Greenland) are associated with anthropogenic $\mathrm{SO}_{2}$ emissions; in the southern hemisphere, nucleation is triggered both by oceanic DMS and anthropogenic $\mathrm{SO}_{2}$. It should be noted that the relative contributions of anthropogenic and natural $\mathrm{SO}_{2}$ to nucleation farther away from anthropogenic source regions are not addressed here.

Owing to higher temperatures, nucleation rates in the boundary layer at tropical latitudes $\left(30^{\circ} \mathrm{S}-30^{\circ} \mathrm{N}\right.$, except some regions with high $\mathrm{SO}_{2}$ source) are negligible even though $\mathrm{H}_{2} \mathrm{SO}_{4}$ gas concentrations are at medium level (see Fig. 1c). Particle formation over the Antarctica occurs mainly during the austral summer season. The simulations also indicate that nucleation induced by anthropogenic $\mathrm{SO}_{2}$ emission contributes to particle abundances in the southern hemisphere. The high nucleation zone along the Chile coast in South American appears to be a significant source of new particle in the southern hemisphere. The relatively higher nucleation rate over Antarctica is due to lower CS, colder temperatures, and higher ionization rates. By contrast, annual mean nucleation rates in the Arctic region $\left(\sim 70^{\circ} \mathrm{N}-90^{\circ} \mathrm{N}\right)$ are much lower due to relatively high concentrations of preexisting particles associated with regional pollution (Arctic haze). 

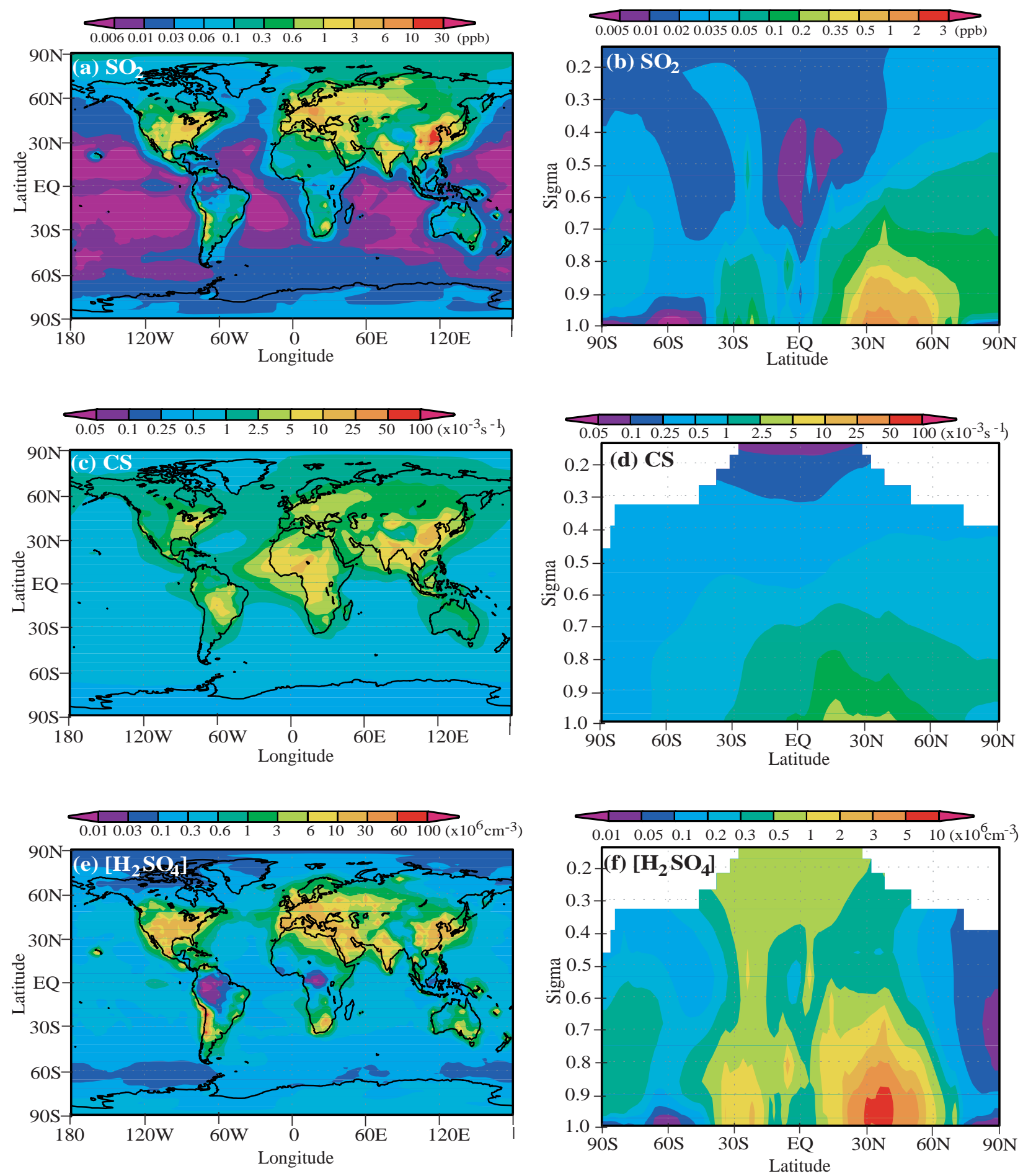

Fig. 1. Horizontal (a, c, e: average over first seven model layers above Earth's surface) and vertical (b, d, f: sigma=pressure/surface pressure) distributions of annual mean values of $\mathrm{SO}_{2}$ mixing ratio, condensation sink (CS), and $\left[\mathrm{H}_{2} \mathrm{SO}_{4}\right]$. We run the GEOS-Chem coupled with nucleation model for one year from 07/01/2001 to 06/30/2002. The time step for transport is 15 minutes and for chemistry (and nucleation) is 30 minutes. The calculations of $\mathrm{CS},\left[\mathrm{H}_{2} \mathrm{SO}_{4}\right]$, and hence nucleation rates are only limited to grid boxes below GEOS-Chem's annual mean tropopause. 


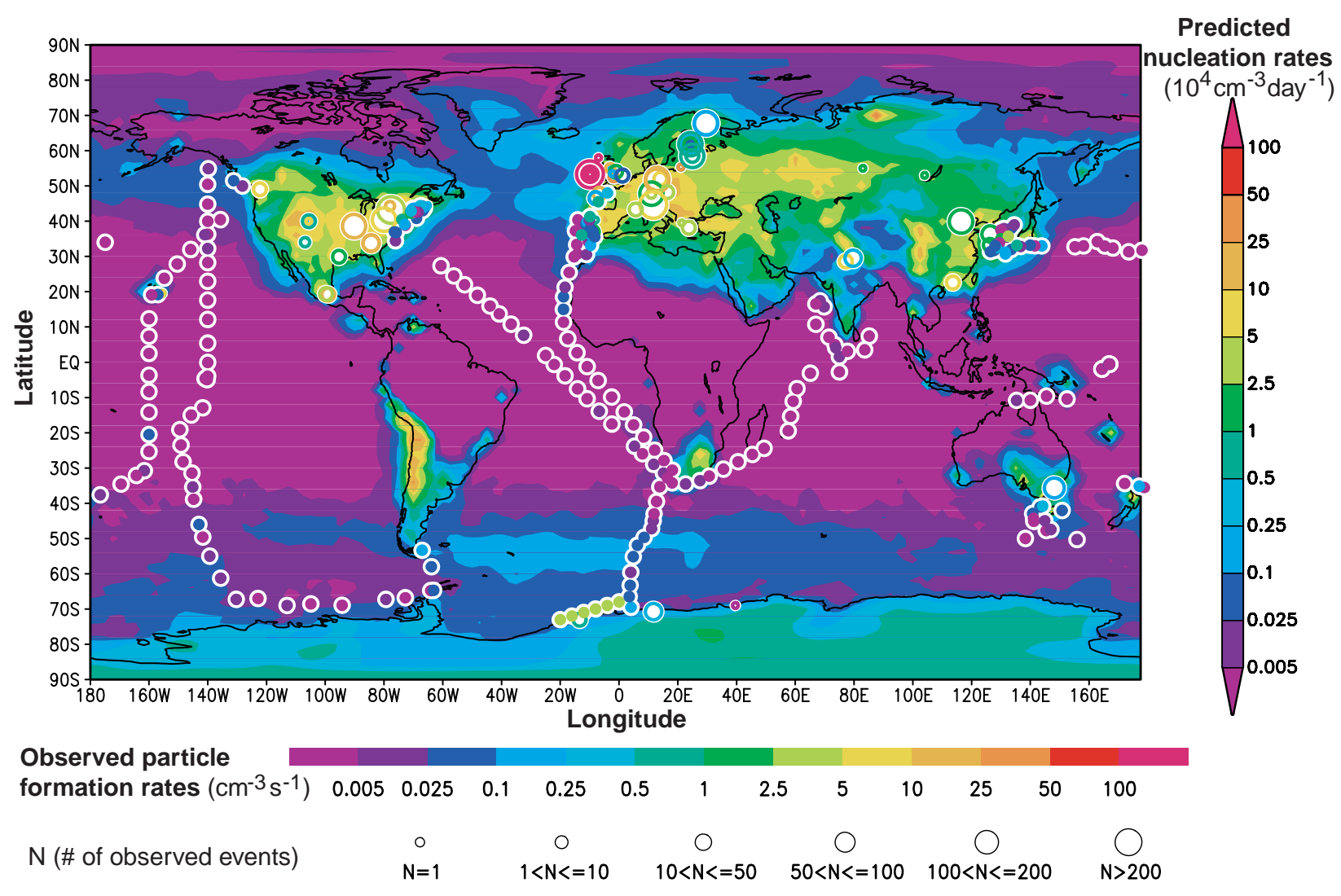

Fig. 2. Simulated global distribution of annual mean nucleation rates averaged within the boundary layer $(0-930 \mathrm{~m})$ (refer to the color bar on the right). Corresponding measured particle formation rates from ship observations are shown as color-filled circles (refer to the lower color bar, which gives the average local nucleation rate, typically over a window of several hours). Measurements over land are indicated by unfilled circles, where circle size defines the number of nucleation events reported (refer to the scale at the bottom of the figure), while color gives the average nucleation rate over the event ensemble. Land-based nucleation data prior to 2004 are taken from Kulmala et al. (2004); after 2004, publications listed in Table 1 are used. Ship-based nucleation rates are derived from the recorded time-series of ultrafine particle concentrations at sizes between $\sim 3 \mathrm{~nm}$ and $\sim 12 \mathrm{~nm}$ (Appendix Table A1). Assuming that typical nucleation events last for 3 hours, an observed nucleation rate of 1 particle $\mathrm{cm}^{-3} \mathrm{~s}^{-1}$ is equivalent to roughly $10^{4}$ particles $\mathrm{cm}^{-3}$ day $^{-1}$; this equivalence has been used to cross-calibrate the color bars in the figure.

Most of the land-based measurements were taken in Western Europe and North America. Ship data, which span the major ocean basins, show negligible particle formation over tropical seas $\left(\sim 30^{\circ} \mathrm{S}-30^{\circ} \mathrm{N}\right)$. It should be noted that the model results represent annual mean nucleation rates (averaged over periods that may or may not include nucleation events) for each $2^{\circ} \times 2.5^{\circ}$ grid cell, while the observations represent average "apparent" particle formation rates based on measured particle concentrations (mostly of sizes $\sim 3 \mathrm{~nm}$ or larger) detected during nucleation events at specific locations. The fraction of freshly nucleated particles $(\sim 1.5 \mathrm{~nm})$ that can grow to measurable size depends on the local growth rate and coagulation lifetime. While the comparison between simulations and observations shown in Fig. 2 is qualitative and limited, it is the first of the kind and Fig. 2 shows that, overall, the predicted spatial pattern of aerosol formation agrees quite well with measurements. The comparison also reveals regions with high predicted nucleation rates in middle-western United States, Canada, Middle East, Eastern Europe, Greenland, Asia, Chile, and Antarctica where nucleation measurements are sparse. Measurements in these regions would therefore be useful for improving our understanding of particle nucleation in the global atmosphere. It should be pointed out that nucleation events do not occur every day of the year. At some sites where long-term nucleation measurements are available ( $N>100$ in Fig. 2), nucleation events typically occur on about one third of the days (i.e., nucleation frequency=1/3). Considering the qualitative nature of the comparison, and the fact that some observations do not persist long enough to derive meaningful nucleation frequency, the observed values in Fig. 2 are not weighted by the nucleation frequency. Multiplying the average observed particle formation rates by nucleation frequency would reduce the equivalent observed values by a factor of around 3 , 
Table 2. Steady state ion-mediated nucleation rates $\left(\mathrm{cm}^{-3} \mathrm{~s}^{-1}\right)$ at critical size $\left(J_{\text {crit }}\right)$ and $3 \mathrm{~nm}\left(J_{3 \mathrm{~nm}}\right)$ under a number of different combinations of sulfuric acid concentration $\left(\left[\mathrm{H}_{2} \mathrm{SO}_{4}\right]\right.$, read $1 \mathrm{E} 7$ as $\left.10^{7} \mathrm{~cm}^{-3}\right)$, surface area of preexisting particles $\left(\mathrm{S}_{0}, \mu \mathrm{m}^{2} \mathrm{~cm}^{-3}\right)$, and ionization rate (Q, ion-pairs $\mathrm{cm}^{-3} \mathrm{~s}^{-1}$ ). $D_{\text {crit }}$ is the diameter (in $\mathrm{nm}$ ) of critical clusters. $T=280 \mathrm{~K}, \mathrm{RH}=50 \%$, Condensation of organics is not considered.

\begin{tabular}{lccccccr}
\hline $\mathrm{S}_{0}$ & {$\left[\mathrm{H}_{2} \mathrm{SO}_{4}\right]$} & $\mathrm{Q}$ & $D_{\text {crit }}$ & $J_{\text {crit }}$ & $J_{3 \mathrm{~nm}}$ & $J_{3 \mathrm{~nm}} / J_{\text {crit }}$ & $J_{3 \mathrm{~nm}} /(2 * \mathrm{Q})$ \\
\hline 50 & $5 \mathrm{E} 6$ & 5 & 1.6 & 0.22 & 0.032 & $15 \%$ & $0.3 \%$ \\
51 & $1 \mathrm{E} 7$ & 5 & 1.45 & 1.82 & 0.68 & $37 \%$ & $6.8 \%$ \\
64 & $5 \mathrm{E} 7$ & 5 & 1.37 & 5.64 & 3.47 & $62 \%$ & $34.7 \%$ \\
100 & $1 \mathrm{E} 8$ & 5 & 1.35 & 5.95 & 4.05 & $68 \%$ & $40.5 \%$ \\
224 & $5 \mathrm{E} 7$ & 5 & 1.37 & 4.1 & 1.63 & $40 \%$ & $16.3 \%$ \\
260 & $1 \mathrm{E} 8$ & 5 & 1.35 & 5.06 & 2.87 & $57 \%$ & $28.7 \%$ \\
606 & $1 \mathrm{E} 8$ & 5 & 1.35 & 3.1 & 1.05 & $34 \%$ & $10.5 \%$ \\
742 & $2 \mathrm{E} 8$ & 5 & 1.34 & 4.3 & 1.96 & $46 \%$ & $19.6 \%$ \\
& & & & & & & \\
260 & $1 \mathrm{E} 8$ & 20 & 1.35 & 17.2 & 9.0 & $52 \%$ & $22.5 \%$ \\
606 & $1 \mathrm{E} 8$ & 20 & 1.35 & 11.4 & 3.7 & $32 \%$ & $9.3 \%$ \\
742 & $2 \mathrm{E} 8$ & 20 & 1.34 & 15.5 & 6.6 & $43 \%$ & $16.5 \%$ \\
& & & & & & & \\
224 & $5 \mathrm{E} 7$ & 50 & 1.37 & 27.4 & 10.1 & $37 \%$ & $10.1 \%$ \\
260 & $1 \mathrm{E} 8$ & 50 & 1.35 & 36.5 & 18.2 & $50 \%$ & $18.2 \%$ \\
\hline
\end{tabular}

(a) Simulated annual mean zonal-averaged nucleation rates $\left(10^{4} \mathrm{~cm}^{-3} \mathrm{day}^{-1}\right)$

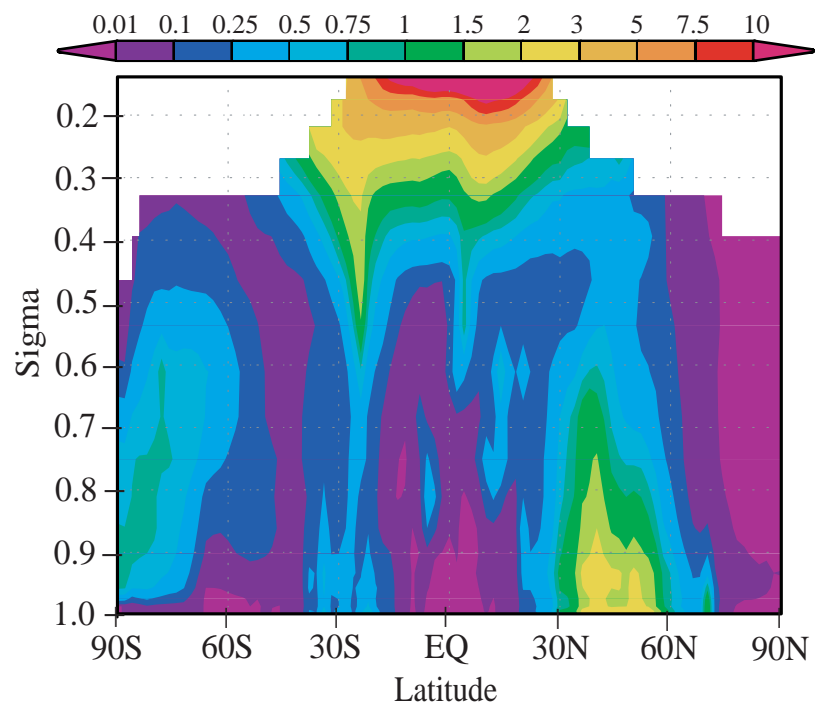

(b) Observed zonal-averaged ultrafine particle concentrations $\left(\mathrm{cm}^{-3}\right)$

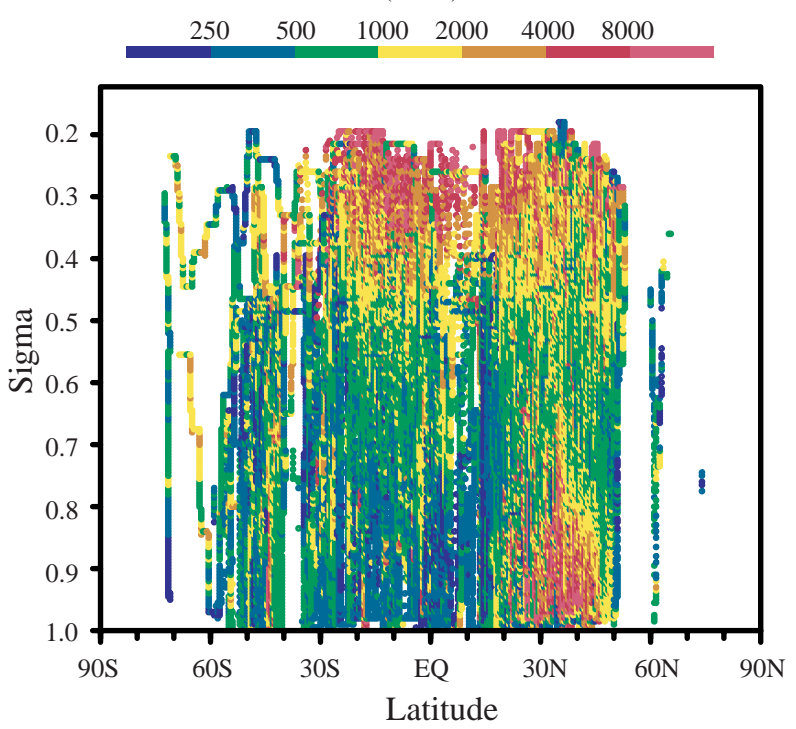

Fig. 3. (a) Meridional structure of predicted annual-mean zonally-averaged nucleation rates calculated using GEOS-Chem coupled to an ion-mediated nucleation sub-model. (b) Zonally-averaged latitudinal and vertical distributions of total ultrafine condensation nuclei (UCN) concentrations measured in situ (Sect. 3.3). In panel 3b, to avoid overlap owing to the large number of data points, the pressure-latitude cross section is divided into a $5 \mathrm{mb} \times 0.5^{\circ}$ grid, wherein all data, at all longitudes, are averaged. The average value for each grid point is represented as a color-coded circle. The observed UCN concentrations have also been normalized to standard conditions ( $1 \mathrm{~atm}, 298 \mathrm{~K})$.

but would not change the conclusions of the paper. The IMN rate is limited by the local ionization rate, roughly $\sim 10$ ionpairs $\mathrm{cm}^{-3} \mathrm{~s}^{-1}$ in the continental surface layer, and $\sim 2$ ionpairs $\mathrm{cm}^{-3} \mathrm{~s}^{-1}$ in the surface layer over oceans (and snow or ice). The fraction of ions that are lost before inducing nucleation, and the fraction of nucleated particles that are scav- enged before growing to sizes $>3 \mathrm{~nm}$, depend on precursor vapor concentration (growth rate), the surface area density $\left(\mathrm{S}_{0}\right)$ of pre-existing particles, and other factors including $T$ and $\mathrm{RH}$. It should be noted that, while $\mathrm{S}_{0}$ in polluted regions is quite large, the concentration of precursor gases can be very high as well. For example, the measured $\left[\mathrm{H}_{2} \mathrm{SO}_{4}\right]$ can 
reach as high as $2 \times 10^{8} \mathrm{~cm}^{-3}$ in Atlanta, Georgia (McMurry et al., 2005) and $8.8 \times 10^{7} \mathrm{~cm}^{-3}$ in anthropogenic plumes advecting from Asia (Weber et al., 2003).

Table 2 gives the steady state ion-mediated nucleation rates at the critical size $\left(J_{\text {crit }}\right)$ and at $3 \mathrm{~nm}\left(J_{3 \mathrm{~nm}}\right.$, i.e., the "apparent" formation rates as observed) under a number of different combinations of sulfuric acid concentration and surface area of preexisting particles. The percentage of nucleated particles (with sizes of $D_{\text {crit }}$ ) growing to $3 \mathrm{~nm}$ $\left(J_{3 \mathrm{~nm}} / J_{\text {crit }}\right)$ and the fraction of ionization "leading" to the formation of $3 \mathrm{~nm}$ particles $\left(J_{3} \mathrm{~nm} /\left(2^{*} \mathrm{Q}\right)\right)$ are also given. The results were based on the simulations using a size-resolved kinetic IMN model that takes into account the scavenging of ions and nucleated particles by pre-existing larger particles and oppositely-charged ions/particles (Yu, 2006a). It is clear from Table 2 that a significant fraction of ions can lead to nucleation and a large fraction of the nucleated particles can grow into observable size range of $>3 \mathrm{~nm}$, even in the polluted regions. It should be noted that the possible contribution of certain organics to the growth of nucleated particles is not considered in the results shown in Table 2. The enhanced growth rates as a result of organic condensation will increase the fraction of nucleated particles growing into observable range.

Most observed particle production rates (Kulmala et al., 2004, also see Table 1) fall below the background ionizationrate limit ( $\sim 20$ ions $\mathrm{cm}^{-3} \mathrm{~s}^{-1}$ over continental sites). An obvious exception is the extremely high rate of particle formation (well above $1000 \mathrm{~cm}^{-3} \mathrm{~s}^{-1}$ and up to $\sim 10^{5} \mathrm{~cm}^{-3} \mathrm{~s}^{-1}$ ) observed in the clean marine coastal environment at Mace Head (O'Dowd et al., 1998). It seems that these anomalously high nucleation rates are linked to the occurrence of low tides and may be associated with homogeneous nucleation of iodine species (O'Dowd et al., 2002). Some measurements also yield particle formation rates that exceed the assumed IMN ionization limit. In this case, possible explanations include:

1. Homogeneous nucleation mechanisms that involve other species, which remain to be identified.

2. Nucleation in exhaust streams that are not fully diluted prior to sampling, where binary homogeneous nucleation can lead to very high levels of nanoparticles (Du and $\mathrm{Yu}, 2006$ ).

3. Enhanced particle formation at locations where the ambient ionization rate exceeds $\sim 10$ ion-pairs $\mathrm{cm}^{3} \mathrm{~s}^{-1}$. Indeed, some measurements indicate that ionization rates near the surface can exceed 100 ion-pairs $\mathrm{cm}^{3} \mathrm{~s}^{-1}$ due to the accumulation of radon gas in the nocturnal boundary layer (Dhanorkar and Kamra, 1994). Recently, Vartiainen et al. (2007) detected exceptionally high ion production rates of up to 30 ion-pairs $\mathrm{cm}^{-3} \mathrm{~s}^{-1}$ during some measurement periods. In urban zones, corona discharge may generate high concentrations of small ions as well.

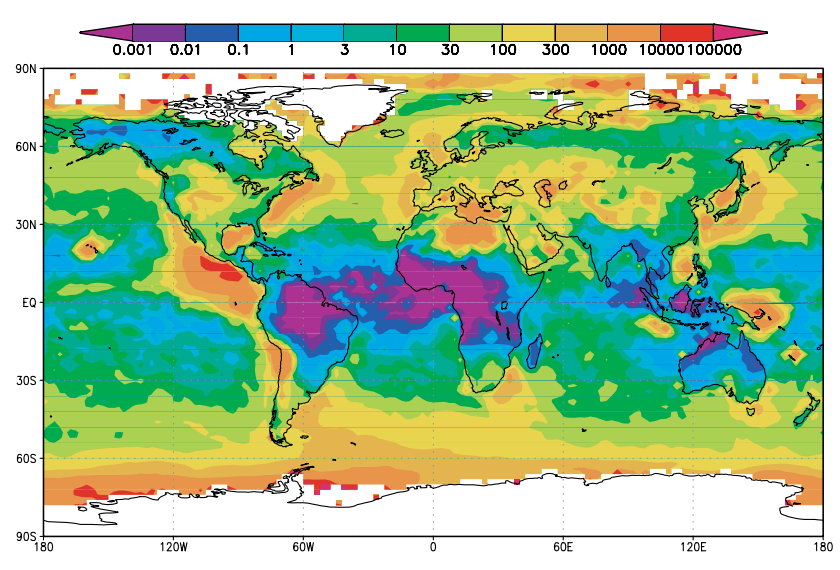

Fig. 4. The ratio of annual mean IMN rates integrated within the lowest $3 \mathrm{~km}$ of atmosphere (e.g., the source strength due to IMN, $\mathrm{SS}_{\text {IMN0-3 }}, \# \mathrm{~cm}^{-2} \mathrm{day}^{-1}$ ) to the annual mean rate of emission of primary particles (e.g., source strength due to primary aerosol emission, $\left.\mathrm{SS}_{\text {primary }}, \# \mathrm{~cm}^{-2} \mathrm{day}^{-1}\right)$. The primary aerosols considered in GEOS-Chem, and their corresponding assumed (fixed) sizes (radius), are: dust (4 sizes: 0.7, 1.5, 2.5, $4 \mu \mathrm{m}$ ), sea salt (3 sizes: 0.732 , $5.67 \mu \mathrm{m}$, and an ultrafine sea salt mode with a radius of $40 \mathrm{~nm})$, black carbon aerosol $(39 \mathrm{~nm})$, and organic carbon particles $(70 \mathrm{~nm})$.

Small ion concentrations of up to $10^{4}-10^{5} \mathrm{~cm}^{-3}$ have been observed near and downwind of high voltage Transmission lines (Carter and Johnson, 1988; Suda and Sunaga, 1990; Grabarczyk and Berlinski, 2005). Higher ion production rate generally leads to enhanced nucleation in the lower troposphere (see Table 2).

4. The inferred high rates of particle formation based on ultrafine particle concentrations may be a result of rapid mixing of particles formed elsewhere during an unknown period of time (Stanier et al., 2004). In many nucleation events reported in the literature, apparent particle formation rates (for example $J_{3} \mathrm{~nm}$ ) are calculated based on time series of the concentrations of freshly nucleated particles (for example, $N_{3-20 \mathrm{~nm}}$, i.e. concentration of particles in the size range of $3-20 \mathrm{~nm}$ ). This is a valid approach when the air mass during the nucleation period is spatially homogeneous. In such cases, the evolution of particle number size distributions shows a well defined "banana" shape (for example, see Fig. 1 in Qian et al., 2007). However, in many observations, particles in the size range of 3-20 nm appear simultaneously (i.e., no time delay in the appearance of the peak values of $N_{3 \mathrm{~nm}}$ and $N_{10 \mathrm{~nm}}$ ), and the evolution of the particle size distribution has the "apple" shape rather than the "banana" shape (for example, see Fig. $3 b$ in Wu et al., 2007; Fig. 10 in Mozurkewich et al., 2004; Fig. 5 in Petäjä et al., 2007; Fig. 7 in Iida et al., 2006). In these cases, the observed increases in $N_{3-20 \mathrm{~nm}}$ are likely a result of mixing or transport of particles nucleated somewhere else, and the particle formation rates 
derived from $\mathrm{d} N_{3-20 \mathrm{~nm}} / \mathrm{dt}$ may be significantly overestimated if the change of air mass is quick. In other words, transport and mixing can make 3-20

,nm particles "pop" up rapidly at a measurement site and thus mimick very fast nucleation in conditions that would support nucleation only at a much lower rate.

Figure 3a shows GOES-IMN simulated annual-mean zonally-averaged nucleation rates as a function of sigma (=pressure/surface pressure) and latitude. It is clear that while nucleation rates are generally small in the lower tropical atmosphere, very high nucleation rates are predicted in middle and upper tropical air layers associated with very low temperature, high ionization rate, and lower condensation sink. High nucleation rates are also obvious in the whole mid-latitude troposphere $\left(25^{\circ} \mathrm{N}-75^{\circ} \mathrm{N}\right)$ in the northern hemisphere although the nucleation rates decrease with altitude. Nucleation appears to be negligible in most northern part of the troposphere $\left(\sim 75^{\circ} \mathrm{N}\right.$ and north). In the southern hemisphere, nucleation in the middle troposphere over Antarctica is significant and nucleation zone extends to $\sim 60^{\circ} \mathrm{S}$. Ito (1993) reported that bimodal size distribution with a trough at around $20 \mathrm{~nm}$ in diameter was observed at Syowa station $\left(69^{\circ} \mathrm{S}, 39^{\circ} 35^{\prime} \mathrm{E}\right)$ in almost all the days from August to December in 1978. Deshpande and Kamra (2004) observed very high concentrations (as high as $10^{4} \mathrm{~cm}^{-3}$ ) of nucleation mode particles around $10 \mathrm{~nm}$ in diameter associated with subsidence of midtropospheric air at the Indian Antarctica station, Maitri $\left(70^{\circ} 45^{\prime} \mathrm{S}, 11^{\circ} 44^{\prime} \mathrm{E}\right)$. It appears that these measurements support our simulations which indicate the existence of a nucleation zone over the Antarctica. The nucleation zone in the lower troposphere around $30^{\circ} \mathrm{S}$ is primarily a result of anthropogenic $\mathrm{SO}_{2}$ emissions (also see Fig. 1). The strong nucleation zone in the middle to upper troposphere around $30^{\circ} \mathrm{S}$ appears to be mainly associated with the continuously active volcano Lascar in Chile which injects $2400 \mathrm{Mg}$ of $\mathrm{SO}_{2}$ per day at an altitude of around $5.6 \mathrm{~km}$.

The total concentrations of particles larger than $\sim 3 \mathrm{~nm}$ have been measured at various altitudes, latitudes, and longitudes with aircraft-based ultrafine condensation nuclei (UCN) counters. While it is difficult to derive in situ particle formation rates directly from these data owing to rapid changes in air mass, UCN concentrations nevertheless can be used as indicators of nucleation, since high UCN concentrations are generally associated with large nucleation rates. Figure $3 \mathrm{~b}$ summarizes the zonally-averaged latitudinal and vertical distributions of total UCN concentrations measured during a number of field campaigns covering a wide range of areas and seasons (see Sect. 3.3). The high UCN regions in the upper troposphere and northern mid-latitude troposphere, and lower UCN in tropical lower troposphere are consistent with corresponding high or low nucleation rates in Fig. 3a (keeping in mind that the nucleation rates in Fig. 3a represent zonal and temporal averages, while the UCN concentrations in Fig. $3 \mathrm{~b}$ represent measurements at selected loca- tions and times). While the comparison between Fig. 3a and Fig. $3 b$ should be considered qualitative, it is the first attempt to compare global nucleation zones with aircraft-based UCN measurements. Figure 3 indicates that the IMN mechanism appears to capture the vertical spatial patterns in the UCN distribution for the regions where sufficient data are available to discern larger-scale patterns. High concentrations of ultrafine particles were also observed during the upper systematic tropospheric transequatorial Africa flights (Heintzenberg et al., 2003). These data are not included in Fig. $3 \mathrm{~b}$ but are generally consistent with Fig. 3. Aircraft-based measurements at higher latitudes in both hemispheres are currently lacking to verify our model predictions.

The general agreement between simulations and observations demonstrated above suggests that IMN may play an important role in generating new particles in global troposphere. Figure 4 compares the annual mean IMN rates integrated over the lowest $3 \mathrm{~km}$ of atmosphere (e.g., the source strength due to IMN, $\mathrm{SS}_{\text {IMN0-3 }}, \# \mathrm{~cm}^{-2} \mathrm{day}^{-1}$ ) with the annual mean source of primary particles due to emissions (e.g. the source strength of primary emissions, $\mathrm{SS}_{\text {primary }}, \# \mathrm{~cm}^{-2}$ day $^{-1}$ ) in terms of the ratio of $\mathrm{SS}_{\mathrm{IMN0}-3}$ to $\mathrm{SS}_{\text {primary. The }}$ results in Fig. 4 clearly indicate that IMN is a significant source of particles throughout the lower troposphere. At high latitudes $\left(\sim 30^{\circ} \mathrm{N}-90^{\circ} \mathrm{N}, 30^{\circ} \mathrm{S}-90^{\circ} \mathrm{S}\right)$, the ratio exceeds 10 over oceans, and lies between $\sim 10$ and $\sim 300$ over land. In the tropics $\left(30^{\circ} \mathrm{S}-30^{\circ} \mathrm{N}\right), \mathrm{SS}_{\mathrm{IMN0}-3} / \mathrm{SS}_{\text {primary }}$ is generally between 0.1 and 10, although some spots have very high ratio and some others spots have very low ratio.

In discussing the relative contribution of secondary particle formation versus primary particle emission to climate active particles, we should keep in mind that the diameters of freshly nucleated particles are just a few nanometers, while those of primary particles are generally greater than $50 \mathrm{~nm}$. The fraction of nucleated particles that grow to $\mathrm{CCN}$ sizes depends on the local growth rates (and, hence, the precursor vapor concentrations), and on the concentration of preexisting particles. Pierce and Adams (2007) found that the probability of a nucleated particle generating a $\mathrm{CCN}$ varies from $<0.1 \%$ to $>90 \%$ in different regions of the atmosphere, and falls between 5\% and $40 \%$ for a large fraction of nucleated particles in the boundary layer. Clearly, with these statistics in mind, IMN is very likely to be a significant source of particles that impact climate. It should be noted that the ratios shown in Fig. 4 do not include the contributions of new particle formation in the middle and upper troposphere. Some of the particles nucleated in the middle and upper troposphere will contribute to the climate effective particles due to their relatively long lifetime (against scavenging by pre-existing particles), although the particle growth rates in these regions are typically small. The evolution of nucleated particles into $\mathrm{CCN}$ should be analyzed using a sizeresolved aerosol microphysical model coupled to global code like GEOS-Chem. 


\section{Summary and discussion}

The magnitude of the aerosol indirect radiative forcing is poorly constrained in climate models, and this is the dominant uncertainty in assessing climate change. The aerosol indirect radiative forcing is largely determined by the number abundance of particles that can act as cloud condensation nuclei $(\mathrm{CCN})$. A clear understanding of the contribution of new particle formation and growth to $\mathrm{CCN}$ abundance, which is essential to properly assess the influences of aerosols on climate, depends on our ability to predict accurately the rates of new particle formation in large-scale models. Significant theoretical and experimental progresses have been made in last couple of years with regard to the role of ions in the formation of tropospheric particles.

In this study, we integrate a recently updated ion-mediated nucleation (IMN) mechanism into a global chemical transport model (GEOS-Chem) to investigate the significance of IMN mechanism as a global source of new particles and the spatial distribution of nucleation zone. We run the GEOSChem coupled with nucleation mechanism for one year from $07 / 01 / 2001$ to $06 / 30 / 2002$, using GEOS-3 grid with $2^{\circ} \times 2.5^{\circ}$ horizontal resolution and 30 vertical levels. The time step for chemistry (and nucleation) is $30 \mathrm{~min}$. Our simulations indicate that IMN can lead to significant new particle production.

Horizontally, a comparison of simulated annual mean particle formation rates in boundary layer with a comprehensive dataset of land- and ship- based nucleation measurements suggests that IMN mechanism may be able to account for many of the observed nucleation events. Vertically, the simulated high and low regions of annual-mean zonally-averaged nucleation rates appears to be consistent with high and low zones of UCN concentrations measured during a number of aircraft-based field campaigns. While the comparison between simulations and observations shown in this study is qualitative and limited, it is the first of the kind and, overall, the predicted spatial pattern of aerosol formation agrees quite well with measurements. The comparison also reveals regions with high predicted nucleation rates where nucleation measurements are sparse and thus identifies the regions where possible future nucleation measurements should be carried out to improve our understanding of particle nucleation in the global atmosphere.

Particle formation rates are sensitive to $\left[\mathrm{H}_{2} \mathrm{SO}_{4}\right]$. One of major uncertainties in our simulated results is associated with the accuracy of the calculated $\left[\mathrm{H}_{2} \mathrm{SO}_{4}\right]$. In addition to the uncertainty in the simulated $\mathrm{SO}_{2}$ concentrations which depend on emission, transport, and loss processes, the uncertainty in the condensation sink (CS) estimated from the simulated mass and assumed size of particles of different types also influence the accuracy of $\left[\mathrm{H}_{2} \mathrm{SO}_{4}\right]$. In addition, the contribution of nucleation mode particles to CS is not considered in current model. To resolve the issue and to study the contribution of nucleation to $\mathrm{CCN}$ in different global environments, we will include size-resolved aerosol microphysics processes in GEOS-Chem in our future study.

Similar to other nucleation schemes that have been used in the global models to predict new particle formation, the IMN mechanism is subject to uncertainty as well. First, the thermodynamic data and physical algorithms used in the IMN model have limitation and uncertainties. Second, species other than $\mathrm{H}_{2} \mathrm{SO}_{4}$ and $\mathrm{H}_{2} \mathrm{O}$ (such as $\mathrm{NH}_{3}, \mathrm{HNO}_{3}$, and organics) may affect the properties of small clusters and the nucleation rates in the real atmosphere. These uncertainties may imply that the IMN contribution to new particle formation in the troposphere could be either higher or lower than what we presented in this study. It should be noted that other nucleation mechanisms may also contribute to tropospheric new particle formation. For example, Kulmala et al. (2006) showed that observed new particle formation rates appear to be a function of sulfuric acid concentration to the power from one to two and proposed an activation theory based on the activation of the clusters containing about one sulfuric acid molecule via heterogeneous nucleation. The physics behind the activation theory remains to be further investigated. In addition to improve the nucleation mechanisms through theoretical development, laboratory and field studies, and quantum calculations for small clusters, further research is also needed on the contributions of different nucleation mechanisms to global source of new particles. More detailed and comprehensive comparisons of model predictions with relevant data obtained in various field campaigns will be helpful to assess the successfulness of various nucleation mechanisms in explaining the observed nucleation events and to identify the areas for further improvement in the existing theories.

\section{Appendix A}

Table A1 gives particle formation rates over oceanic surface derived from ship-based condensation nuclei $(\mathrm{CN}$, diameter $>\sim 12 \mathrm{~nm}$ ) and ultrafine condensation nuclei (UCN, diameter $>\sim 3 \mathrm{~m}$ ) measurements. 
Table A1. Ship-based particle formation rates $\left(J_{\text {obs }}\right)$ derived from measurements obtained during 10 ship cruise campaigns. The data in this table are plotted in Fig. 2 of the main text.

\begin{tabular}{|c|c|c|}
\hline $\begin{array}{l}\text { Latitude } \\
\text { (degree) }\end{array}$ & $\begin{array}{l}\text { Longitude } \\
\text { (degree) }\end{array}$ & $\begin{array}{l}J_{\mathrm{obs}} \\
\left(\# \mathrm{~cm}^{-3} \mathrm{~s}^{-1}\right)\end{array}$ \\
\hline \multicolumn{3}{|l|}{ (1)RITS94 } \\
\hline 49.98 & -128.20 & $1.5 \mathrm{E}-02$ \\
\hline 51.49 & -131.20 & 4.6E-02 \\
\hline 54.90 & -139.80 & $1.6 \mathrm{E}-02$ \\
\hline 50.46 & -140.00 & $1.5 \mathrm{E}-04$ \\
\hline 44.84 & -140.00 & $0.0 \mathrm{E}+00$ \\
\hline 39.99 & -140.00 & $0.0 \mathrm{E}+00$ \\
\hline 36.31 & -140.00 & $2.8 \mathrm{E}-03$ \\
\hline 32.24 & -140.00 & $5.6 \mathrm{E}-03$ \\
\hline 28.27 & -140.00 & $3.4 \mathrm{E}-03$ \\
\hline 22.95 & -140.00 & $6.6 \mathrm{E}-05$ \\
\hline 17.62 & -140.00 & $0.0 \mathrm{E}+00$ \\
\hline 12.14 & -140.00 & 7.6E-05 \\
\hline 5.42 & -140.00 & 4.9E-05 \\
\hline-0.07 & -140.00 & 4.5E-04 \\
\hline-3.97 & -140.00 & $0.0 \mathrm{E}+00$ \\
\hline-4.95 & -140.20 & $2.6 \mathrm{E}-04$ \\
\hline-4.85 & -140.40 & $9.2 \mathrm{E}-04$ \\
\hline-4.75 & -140.50 & 7.8E-04 \\
\hline-4.62 & -140.90 & $1.1 \mathrm{E}-03$ \\
\hline-12.93 & -141.70 & $1.7 \mathrm{E}-03$ \\
\hline-14.99 & -145.60 & $0.0 \mathrm{E}+00$ \\
\hline-19.14 & -149.50 & $2.5 \mathrm{E}-03$ \\
\hline-23.49 & -149.10 & $2.0 \mathrm{E}-03$ \\
\hline-28.24 & -148.40 & $1.9 \mathrm{E}-03$ \\
\hline-31.45 & -145.40 & $1.5 \mathrm{E}-03$ \\
\hline-35.39 & -145.10 & $9.6 \mathrm{E}-03$ \\
\hline-38.88 & -144.80 & $0.0 \mathrm{E}+00$ \\
\hline-46.02 & -143.00 & $5.5 \mathrm{E}-02$ \\
\hline-49.61 & -141.70 & $0.0 \mathrm{E}+00$ \\
\hline-55.01 & -139.30 & $6.1 \mathrm{E}-03$ \\
\hline-61.27 & -135.60 & $9.0 \mathrm{E}-03$ \\
\hline-67.28 & -130.30 & $1.7 \mathrm{E}-02$ \\
\hline-67.02 & -122.90 & 4.7E-03 \\
\hline-69.00 & -113.00 & $1.0 \mathrm{E}-02$ \\
\hline-68.56 & -104.90 & $0.0 \mathrm{E}+00$ \\
\hline-68.95 & -94.26 & $5.0 \mathrm{E}-04$ \\
\hline-67.27 & -79.36 & 8.1E-03 \\
\hline-66.81 & -72.76 & $0.0 \mathrm{E}+00$ \\
\hline-64.78 & -64.08 & 4.7E-03 \\
\hline-64.71 & -63.10 & $2.9 \mathrm{E}-02$ \\
\hline-58.01 & -63.88 & $3.9 \mathrm{E}-02$ \\
\hline-53.34 & -67.03 & $2.4 \mathrm{E}-01$ \\
\hline
\end{tabular}

Table A1. Continued.

\begin{tabular}{|c|c|c|}
\hline $\begin{array}{l}\text { Latitude } \\
\text { (degree) }\end{array}$ & $\begin{array}{l}\text { Longitude } \\
\text { (degree) }\end{array}$ & $\begin{array}{l}J_{\mathrm{obs}} \\
\left(\# \mathrm{~cm}^{-3} \mathrm{~s}^{-1}\right)\end{array}$ \\
\hline \multicolumn{3}{|c|}{ (2) INDOEX99 } \\
\hline 27.37 & -60.62 & $7.6 \mathrm{E}-04$ \\
\hline 24.48 & -56.26 & $9.5 \mathrm{E}-04$ \\
\hline 21.99 & -52.59 & $1.9 \mathrm{E}-03$ \\
\hline 18.99 & -48.23 & $3.7 \mathrm{E}-03$ \\
\hline 15.94 & -43.90 & $2.5 \mathrm{E}-03$ \\
\hline 13.72 & -40.78 & $2.6 \mathrm{E}-03$ \\
\hline 10.79 & -36.73 & $1.6 \mathrm{E}-03$ \\
\hline 7.66 & -32.46 & $8.1 \mathrm{E}-03$ \\
\hline 1.93 & -25.01 & $0.0 \mathrm{E}+00$ \\
\hline-0.64 & -22.07 & $0.0 \mathrm{E}+00$ \\
\hline-3.86 & -18.39 & $0.0 \mathrm{E}+00$ \\
\hline-7.55 & -14.13 & $1.6 \mathrm{E}-03$ \\
\hline-10.36 & -10.89 & $0.0 \mathrm{E}+00$ \\
\hline-13.90 & -6.74 & $5.5 \mathrm{E}-03$ \\
\hline-17.53 & -2.44 & $8.1 \mathrm{E}-05$ \\
\hline-23.82 & 5.25 & $6.1 \mathrm{E}-03$ \\
\hline-25.98 & 7.98 & $6.9 \mathrm{E}-04$ \\
\hline-28.97 & 11.80 & $6.0 \mathrm{E}-03$ \\
\hline-31.47 & 15.13 & $9.1 \mathrm{E}-03$ \\
\hline-34.22 & 18.07 & $0.0 \mathrm{E}+00$ \\
\hline-34.53 & 22.64 & $1.0 \mathrm{E}-02$ \\
\hline-33.58 & 27.55 & $1.2 \mathrm{E}-02$ \\
\hline-32.30 & 30.71 & $0.0 \mathrm{E}+00$ \\
\hline-30.32 & 35.53 & $0.0 \mathrm{E}+00$ \\
\hline-28.23 & 40.52 & $4.1 \mathrm{E}-03$ \\
\hline-26.15 & 45.39 & $5.8 \mathrm{E}-04$ \\
\hline-24.42 & 49.38 & $4.8 \mathrm{E}-04$ \\
\hline-19.45 & 57.59 & $9.9 \mathrm{E}-04$ \\
\hline-15.34 & 58.43 & 3.7E-04 \\
\hline-11.07 & 59.27 & $1.2 \mathrm{E}-03$ \\
\hline-7.50 & 60.59 & $2.0 \mathrm{E}-04$ \\
\hline-3.12 & 65.12 & 2.7E-03 \\
\hline 15.71 & 69.81 & $2.3 \mathrm{E}-02$ \\
\hline 17.44 & 68.43 & $1.2 \mathrm{E}-02$ \\
\hline 16.55 & 67.00 & $0.0 \mathrm{E}+00$ \\
\hline 10.76 & 67.00 & $1.3 \mathrm{E}-03$ \\
\hline 7.08 & 71.43 & $1.5 \mathrm{E}-03$ \\
\hline 4.98 & 73.48 & 4.4E-03 \\
\hline 1.59 & 75.00 & 7.4E-03 \\
\hline-2.76 & 75.00 & $0.0 \mathrm{E}+00$ \\
\hline 4.10 & 73.76 & $1.9 \mathrm{E}-02$ \\
\hline 3.08 & 77.74 & $0.0 \mathrm{E}+00$ \\
\hline 3.52 & 83.63 & $1.6 \mathrm{E}-03$ \\
\hline 7.42 & 85.17 & $3.5 \mathrm{E}-03$ \\
\hline
\end{tabular}


Table A1. Continued.

\begin{tabular}{lll}
\hline $\begin{array}{l}\text { Latitude } \\
(\text { degree })\end{array}$ & $\begin{array}{l}\text { Longitude } \\
(\text { degree })\end{array}$ & $\begin{array}{l}J_{\text {obs }} \\
\left(\# \mathrm{~cm}^{-3} \mathrm{~s}^{-1}\right)\end{array}$ \\
\hline $\begin{array}{ll}\text { (3) ACE-ASIA } \\
34.03\end{array}$ & -174.90 & $2.7 \mathrm{E}-03$ \\
31.76 & 178.00 & $3.1 \mathrm{E}-03$ \\
31.33 & 173.50 & $2.0 \mathrm{E}-04$ \\
32.39 & 168.10 & $4.5 \mathrm{E}-03$ \\
32.95 & 165.30 & $4.3 \mathrm{E}-03$ \\
34.20 & 162.80 & $0.0 \mathrm{E}+00$ \\
33.00 & 158.10 & $0.0 \mathrm{E}+00$ \\
32.74 & 155.20 & $1.6 \mathrm{E}-03$ \\
33.00 & 143.90 & $1.0 \mathrm{E}-01$ \\
33.01 & 141.50 & $0.0 \mathrm{E}+00$ \\
33.20 & 139.90 & $8.3 \mathrm{E}-02$ \\
32.82 & 136.70 & $2.2 \mathrm{E}-02$ \\
31.96 & 133.50 & $2.9 \mathrm{E}-02$ \\
30.72 & 131.50 & $1.4 \mathrm{E}-01$ \\
31.70 & 127.70 & $5.5 \mathrm{E}-02$ \\
33.45 & 128.60 & $6.2 \mathrm{E}-02$ \\
35.47 & 131.80 & $0.0 \mathrm{E}+00$ \\
38.06 & 133.60 & $3.8 \mathrm{E}-02$ \\
38.97 & 134.50 & $1.7 \mathrm{E}-02$ \\
37.92 & 131.00 & $5.8 \mathrm{E}-03$ \\
37.53 & 130.00 & $0.0 \mathrm{E}+00$ \\
35.01 & 130.00 & $1.9 \mathrm{E}+00$ \\
35.74 & 132.50 & $2.8 \mathrm{E}+00$ \\
33.84 & 129.50 & $0.0 \mathrm{E}+00$ \\
32.52 & 128.40 & $3.0 \mathrm{E}-01$ \\
31.36 & 126.40 & $2.6 \mathrm{E}-02$ \\
33.01 & 128.00 & $8.1 \mathrm{E}-02$ \\
31.22 & 131.40 & $1.9 \mathrm{E}-01$ \\
33.13 & 135.40 & $6.3 \mathrm{E}-01$ \\
\hline & & \\
& & \\
3 & & \\
3 & & \\
3 & &
\end{tabular}

Table A1. Continued.

\begin{tabular}{|c|c|c|}
\hline $\begin{array}{l}\text { Latitude } \\
\text { (degree) }\end{array}$ & $\begin{array}{l}\text { Longitude } \\
\text { (degree) }\end{array}$ & $\begin{array}{l}J_{\mathrm{obs}} \\
\left(\# \mathrm{~cm}^{-3} \mathrm{~s}^{-1}\right)\end{array}$ \\
\hline \multicolumn{3}{|l|}{ (4)ACE2 } \\
\hline 36.94 & -9.40 & $0.0 \mathrm{E}+00$ \\
\hline 35.67 & -10.78 & $5.9 \mathrm{E}-03$ \\
\hline 35.44 & -8.97 & 7.1E-02 \\
\hline 35.92 & -9.00 & 9.9E-02 \\
\hline 38.22 & -12.58 & $2.0 \mathrm{E}-03$ \\
\hline 40.40 & -14.01 & $0.0 \mathrm{E}+00$ \\
\hline 37.27 & -14.86 & $0.0 \mathrm{E}+00$ \\
\hline 37.00 & -8.91 & 8.2E-02 \\
\hline 37.16 & -9.05 & 8.0E-02 \\
\hline 37.16 & -9.05 & $0.0 \mathrm{E}+00$ \\
\hline 38.85 & -10.67 & $0.0 \mathrm{E}+00$ \\
\hline 39.12 & -11.65 & $0.0 \mathrm{E}+00$ \\
\hline 36.30 & -9.86 & $3.2 \mathrm{E}-01$ \\
\hline 36.77 & -9.84 & $3.5 \mathrm{E}-02$ \\
\hline 34.21 & -10.50 & $0.0 \mathrm{E}+00$ \\
\hline 33.40 & -14.40 & $0.0 \mathrm{E}+00$ \\
\hline 30.74 & -14.15 & $0.0 \mathrm{E}+00$ \\
\hline 30.54 & -11.10 & $8.0 \mathrm{E}-03$ \\
\hline 33.15 & -9.70 & $1.0 \mathrm{E}-01$ \\
\hline 35.57 & -8.26 & $5.8 \mathrm{E}-02$ \\
\hline 37.17 & -9.35 & 2.7E-02 \\
\hline 39.22 & -11.29 & 4.7E-02 \\
\hline 39.75 & -10.87 & $1.0 \mathrm{E}-01$ \\
\hline 37.91 & -9.78 & $5.8 \mathrm{E}-02$ \\
\hline 36.71 & -8.94 & $3.1 \mathrm{E}-02$ \\
\hline 36.35 & -9.36 & $0.0 \mathrm{E}+00$ \\
\hline 38.46 & -11.78 & $0.0 \mathrm{E}+00$ \\
\hline 40.32 & -10.07 & $2.4 \mathrm{E}-02$ \\
\hline
\end{tabular}


Table A1. Continued.

\begin{tabular}{lll}
\hline $\begin{array}{l}\text { Latitude } \\
\text { (degree) }\end{array}$ & $\begin{array}{l}\text { Longitude } \\
(\text { degree })\end{array}$ & $\begin{array}{l}J_{\text {obs }} \\
\left(\mathrm{\#} \mathrm{cm}^{-3} \mathrm{~s}^{-1}\right)\end{array}$ \\
\hline (5) ACE1 & & \\
40.44 & -135.70 & $0.0 \mathrm{E}+00$ \\
36.17 & -141.00 & $5.2 \mathrm{E}-03$ \\
31.99 & -145.80 & $0.0 \mathrm{E}+00$ \\
27.85 & -150.40 & $0.0 \mathrm{E}+00$ \\
23.80 & -154.80 & $3.8 \mathrm{E}-04$ \\
19.19 & -157.00 & $5.0 \mathrm{E}-02$ \\
19.12 & -159.10 & $0.0 \mathrm{E}+00$ \\
12.34 & -160.00 & $1.0 \mathrm{E}-03$ \\
7.39 & -160.00 & $3.1 \mathrm{E}-03$ \\
2.49 & -160.00 & $1.2 \mathrm{E}-04$ \\
-3.68 & -160.00 & $7.1 \mathrm{E}-04$ \\
-8.34 & -160.00 & $3.1 \mathrm{E}-04$ \\
-14.14 & -160.00 & $1.0 \mathrm{E}-03$ \\
-20.51 & -160.00 & $5.4 \mathrm{E}-02$ \\
-25.33 & -160.00 & $1.2 \mathrm{E}-03$ \\
-30.76 & -161.60 & $2.2 \mathrm{E}-02$ \\
-32.11 & -164.30 & $7.7 \mathrm{E}-04$ \\
-34.58 & -169.50 & $0.0 \mathrm{E}+00$ \\
-37.61 & -176.60 & $1.1 \mathrm{E}-02$ \\
-35.53 & 178.80 & $0.0 \mathrm{E}+00$ \\
-35.15 & 177.10 & $1.5 \mathrm{E}-01$ \\
-34.40 & 172.10 & $0.0 \mathrm{E}+00$ \\
-42.04 & 150.80 & $3.0 \mathrm{E}-02$ \\
-50.29 & 155.90 & $9.8 \mathrm{E}-03$ \\
-47.75 & 145.40 & $0.0 \mathrm{E}+00$ \\
-49.99 & 138.30 & $0.0 \mathrm{E}+00$ \\
-42.88 & 140.80 & $5.7 \mathrm{E}-02$ \\
-41.08 & 143.30 & $2.6 \mathrm{E}-02$ \\
-40.81 & 144.20 & $2.5 \mathrm{E}-01$ \\
-44.28 & 141.10 & $0.0 \mathrm{E}+00$ \\
-45.14 & 141.20 & $0.0 \mathrm{E}+00$ \\
-47.47 & 147.00 & $8.7 \mathrm{E}-03$ \\
-44.96 & 144.90 & $2.1 \mathrm{E}-02$ \\
\hline & &
\end{tabular}

Table A1. Continued.

\begin{tabular}{lll}
\hline $\begin{array}{l}\text { Latitude } \\
\text { (degree) }\end{array}$ & $\begin{array}{l}\text { Longitude } \\
\text { (degree) }\end{array}$ & $\begin{array}{l}J_{\text {obs }} \\
\left(\# \mathrm{~cm}^{-3} \mathrm{~s}^{-1}\right)\end{array}$ \\
\hline (6) NAURU99 & & \\
-10.82 & 135.30 & $5.8 \mathrm{E}-03$ \\
-10.78 & 140.00 & $0.0 \mathrm{E}+00$ \\
-9.59 & 145.50 & $2.6 \mathrm{E}-03$ \\
-10.42 & 152.50 & $4.5 \mathrm{E}-03$ \\
-1.91 & 164.40 & $0.0 \mathrm{E}+00$ \\
-1.92 & 164.40 & $0.0 \mathrm{E}+00$ \\
-1.92 & 164.40 & $2.6 \mathrm{E}-03$ \\
-1.92 & 164.40 & $3.7 \mathrm{E}-03$ \\
-0.52 & 166.70 & $7.1 \mathrm{E}-03$ \\
-0.52 & 166.90 & $3.6 \mathrm{E}-02$ \\
-0.55 & 166.90 & $5.2 \mathrm{E}-02$ \\
-0.50 & 166.90 & $4.5 \mathrm{E}-03$ \\
-0.56 & 167.00 & $0.0 \mathrm{E}+00$ \\
-0.57 & 167.00 & $0.0 \mathrm{E}+00$ \\
$(7)$ NEAQS02 & & \\
34.45 & -76.11 & $9.6 \mathrm{E}-03$ \\
38.84 & -72.78 & $4.7 \mathrm{E}-03$ \\
40.49 & -73.87 & $1.2 \mathrm{E}+00$ \\
40.44 & -73.80 & $5.9 \mathrm{E}-01$ \\
40.82 & -68.92 & $3.2 \mathrm{E}-02$ \\
42.46 & -70.79 & $8.1 \mathrm{E}-01$ \\
43.02 & -70.33 & $5.8 \mathrm{E}-02$ \\
43.01 & -70.66 & $6.5 \mathrm{E}-01$ \\
42.94 & -70.72 & $2.3 \mathrm{E}-01$ \\
42.83 & -70.71 & $8.3 \mathrm{E}-01$ \\
42.75 & -70.59 & $4.2 \mathrm{E}-01$ \\
43.46 & -70.21 & $1.3 \mathrm{E}-01$ \\
43.40 & -69.37 & $0.0 \mathrm{E}+00$ \\
43.02 & -70.67 & $8.1 \mathrm{E}-01$ \\
42.32 & -70.73 & $9.7 \mathrm{E}-01$ \\
42.40 & -70.77 & $6.4 \mathrm{E}-01$ \\
42.97 & -70.65 & $2.4 \mathrm{E}-01$ \\
42.79 & -70.59 & $9.3 \mathrm{E}-02$ \\
43.02 & -70.68 & $1.8 \mathrm{E}-01$ \\
43.01 & -70.67 & $8.2 \mathrm{E}-02$ \\
42.79 & -70.54 & $1.2 \mathrm{E}-01$ \\
43.02 & -70.64 & $1.7 \mathrm{E}-01$ \\
39.06 & -72.99 & $1.1 \mathrm{E}-01$ \\
36.82 & -75.84 & $5.1 \mathrm{E}-02$ \\
36.97 & -76.44 & $9.5 \mathrm{E}-02$ \\
\hline & & \\
\hline & & \\
& & \\
& & \\
& &
\end{tabular}


Table A1. Continued.

\begin{tabular}{lll}
\hline $\begin{array}{l}\text { Latitude } \\
(\text { degree })\end{array}$ & $\begin{array}{l}\text { Longitude } \\
(\text { degree })\end{array}$ & $\begin{array}{l}J_{\text {obs }} \\
\left(\# \mathrm{~cm}^{-3} \mathrm{~s}^{-1}\right)\end{array}$ \\
\hline $\begin{array}{l}\text { (8) NEAQS04 } \\
42.42\end{array}$ & -70.65 & $2.0 \mathrm{E}+00$ \\
42.51 & -70.56 & $2.3 \mathrm{E}-01$ \\
43.72 & -66.20 & $2.9 \mathrm{E}-01$ \\
43.00 & -66.80 & $7.6 \mathrm{E}-02$ \\
42.46 & -70.35 & $4.6 \mathrm{E}-01$ \\
42.36 & -71.03 & $3.7 \mathrm{E}+00$ \\
42.78 & -70.71 & $2.3 \mathrm{E}+00$ \\
42.41 & -70.74 & $2.0 \mathrm{E}-01$ \\
42.38 & -70.86 & $4.0 \mathrm{E}-01$ \\
42.74 & -70.70 & $7.1 \mathrm{E}-01$ \\
42.74 & -70.73 & $6.2 \mathrm{E}-01$ \\
43.17 & -69.26 & $1.5 \mathrm{E}-01$ \\
44.32 & -67.10 & $2.5 \mathrm{E}-02$ \\
44.00 & -66.59 & $1.2 \mathrm{E}-01$ \\
43.16 & -70.47 & $1.3 \mathrm{E}-01$ \\
42.45 & -70.82 & $6.6 \mathrm{E}-01$ \\
42.80 & -70.51 & $1.4 \mathrm{E}-02$ \\
42.80 & -70.63 & $5.9 \mathrm{E}-02$ \\
42.97 & -70.51 & $0.0 \mathrm{E}+00$ \\
42.67 & -69.77 & $3.8 \mathrm{E}-01$ \\
42.82 & -70.74 & $7.7 \mathrm{E}-02$ \\
43.32 & -70.17 & $2.8 \mathrm{E}-01$ \\
43.09 & -70.44 & $3.9 \mathrm{E}-01$ \\
43.52 & -70.07 & $9.9 \mathrm{E}-01$ \\
43.65 & -69.90 & $2.3 \mathrm{E}-01$ \\
44.39 & -67.62 & $4.7 \mathrm{E}-01$ \\
43.64 & -69.41 & $4.2 \mathrm{E}-01$ \\
43.62 & -70.12 & $1.4 \mathrm{E}-01$ \\
42.55 & -68.38 & $2.3 \mathrm{E}-02$ \\
42.43 & -70.50 & $4.6 \mathrm{E}+00$ \\
42.37 & -71.05 & $1.6 \mathrm{E}+00$ \\
42.63 & -69.61 & $0.0 \mathrm{E}+00$ \\
42.87 & -70.77 & $4.4 \mathrm{E}-01$ \\
\hline & &
\end{tabular}

Table A1. Continued.

\begin{tabular}{|c|c|c|}
\hline $\begin{array}{l}\text { Latitude } \\
\text { (degree) }\end{array}$ & $\begin{array}{l}\text { Longitude } \\
\text { (degree) }\end{array}$ & $\begin{array}{l}J_{\mathrm{obs}} \\
\left(\# \mathrm{~cm}^{-3} \mathrm{~s}^{-1}\right)\end{array}$ \\
\hline \multicolumn{3}{|c|}{ (9)Koponen et al., 2002} \\
\hline-69.50 & 4.06 & $1.0 \mathrm{E}-01$ \\
\hline-66.49 & 3.47 & 7.4E-02 \\
\hline-63.30 & 3.78 & $4.0 \mathrm{E}-02$ \\
\hline-59.59 & 4.00 & $1.0 \mathrm{E}-02$ \\
\hline-55.14 & 4.83 & $5.5 \mathrm{E}-02$ \\
\hline-51.92 & 6.25 & $4.6 \mathrm{E}-02$ \\
\hline-49.69 & 8.52 & $3.4 \mathrm{E}-02$ \\
\hline-47.21 & 11.08 & $1.8 \mathrm{E}-02$ \\
\hline-44.98 & 11.64 & 8.0E-03 \\
\hline-43.00 & 11.92 & $1.0 \mathrm{E}-03$ \\
\hline-39.53 & 12.76 & $1.0 \mathrm{E}-04$ \\
\hline-35.32 & 13.88 & $1.0 \mathrm{E}-04$ \\
\hline-32.84 & 16.44 & $1.0 \mathrm{E}-04$ \\
\hline-30.61 & 18.15 & $1.0 \mathrm{E}-04$ \\
\hline-27.90 & 15.28 & $1.0 \mathrm{E}-04$ \\
\hline-24.93 & 12.12 & $1.0 \mathrm{E}-04$ \\
\hline-21.23 & 8.39 & $1.0 \mathrm{E}-04$ \\
\hline-17.78 & 4.94 & $1.0 \mathrm{E}-04$ \\
\hline-14.07 & 1.78 & $1.0 \mathrm{E}-04$ \\
\hline-9.88 & -2.52 & $1.0 \mathrm{E}-04$ \\
\hline-5.19 & -7.12 & $1.0 \mathrm{E}-04$ \\
\hline-1.24 & -10.85 & $1.0 \mathrm{E}-04$ \\
\hline 2.71 & -14.30 & $1.0 \mathrm{E}-04$ \\
\hline 6.66 & -17.46 & $1.0 \mathrm{E}-04$ \\
\hline 11.36 & -18.91 & $1.0 \mathrm{E}-04$ \\
\hline 15.00 & -18.93 & $4.1 \mathrm{E}-02$ \\
\hline 18.56 & -18.90 & $6.0 \mathrm{E}-02$ \\
\hline 21.26 & -18.39 & $1.0 \mathrm{E}-02$ \\
\hline 25.47 & -16.98 & $1.0 \mathrm{E}-04$ \\
\hline 29.92 & -15.28 & $1.0 \mathrm{E}-04$ \\
\hline 36.12 & -12.74 & 5.7E-01 \\
\hline 41.32 & -9.91 & $6.4 \mathrm{E}-01$ \\
\hline 45.53 & -7.07 & $5.0 \mathrm{E}-01$ \\
\hline 48.01 & -3.94 & 4.0E-01 \\
\hline \multicolumn{3}{|c|}{ (10) Davison et al., 1996} \\
\hline-68.00 & 0.00 & $3.2 \mathrm{E}+00$ \\
\hline-69.00 & -4.00 & $3.2 \mathrm{E}+00$ \\
\hline-70.00 & -8.00 & $3.2 \mathrm{E}+00$ \\
\hline-71.00 & -12.00 & $3.2 \mathrm{E}+00$ \\
\hline-72.00 & -16.00 & $3.2 \mathrm{E}+00$ \\
\hline-73.00 & -20.00 & $3.2 \mathrm{E}+00$ \\
\hline
\end{tabular}


Acknowledgements. This study is supported by the NOAA/DOC under grant NA05OAR4310103, NSF under grant 0618124, and NASA under grant NNX08AK48G. Z. Wang acknowledges the support of the CAS International Partnership Program for Creative Research Teams, National 973 Project (2005CB422205) and NSFC (40533017). The GEOS-Chem model is managed by the Atmospheric Chemistry Modeling Group at Harvard University with support from the NASA Atmospheric Chemistry Modeling and Analysis Program. We thank V. N. Kapustin and A. D. Clark for providing the aircraft-based UCN data. TRACE-P and INTEX-A data are from NASA Global Tropospheric Experiment (GTE) database website. The original ship-based data were obtained from NOAA PMEL Atmospheric Chemistry Data Server.

Edited by: M. Kulmala

\section{References}

Albrecht, B. A.: Aerosols, cloud microphysics and fractional cloudiness, Sciences, 245, 1227-1230, 1989.

Alexander, B., Park, R. J., Jacob, D. J., Li, Q. B., Yantosca, R. M., Savarino, J., C. C. W. Lee, C. C. W., and Thiemens, M. H.: Sulfate formation in sea-salt aerosols: Constraints from oxygen isotopes, J. Geophys. Res., 110, D10307, doi:10.1029/2004JD005659, 2005.

Andreae, M. O. and Merlet, P.: Emission of trace gases and aerosols from biomass burning, Global Biogeochem. Cycles, 15(4), 955966, 2001.

Andres, R. J. and Kasgnoc, A. D.: A time-averaged inventory of subaerial volcanic sulfur emissions, J. Geophys. Res., 103(D19), 25 251-25 262, doi:10.1029/98JD02091, 1998.

Benkovitz, C. M., Scholtz, M. T., Pacyna, J., Tarrason, L., Dignon, J., Voldner, E. C., Spiro, P. A., Logan, J. A., and Graedel, T. E.: Global gridded inventories of anthropogenic emissions of sulfur and nitrogen, J. Geophys. Res., 101(D22), 29,239-29,253, 1996.

Bey, I., Jacob, D. J., Yantosca, R. M., Logan, J. A., Field, B., Fiore, A. M., Li, Q., Liu, H., Mickley, L. J., and Schultz, M.: Global modeling of tropospheric chemistry with assimilated meteorology: Model description and evaluation, J. Geophys. Res., 106(D19), 23 073-23 096, 2001.

Birmili, W., Berresheim, H., Plass-Dülmer, C., Elste, T., Gilge, S., Wiedensohler, A., and Uhrner, U.: The Hohenpeissenberg aerosol formation experiment (HAFEX): a long-term study including size-resolved aerosol, $\mathrm{H} 2 \mathrm{SO} 4, \mathrm{OH}$, and monoterpenes measurements, Atm. Chem. Phys., 3, 361-376, 2003.

Carter, P. J. and Johnson, G. B.: Space charge measurements downwind from a monopolar $500 \mathrm{kV}$ HVDC test line, IEEE Transactions on Power Delivery, 3(4), 2056-2063, 1988.

Charlson, R. J., Schwartz, S. E., Hales, J. M., Cess, R. D., Coakley Jr., J. A., Hansen, J. E., and Hofmann, D. J.: Climate forcing by anthropogenic aerosols, Science, 255, 423-430, 1992.

Chin, M., Rood, R. B., Lin, S.-J., Muüller, J.-F., and Thompson, A. M.: Atmospheric sulfur cycle simulated in the global model GOCART: Model description and global properties, J. Geophys. Res., 105(D20), 24671-24687, 2000.

Clarke, A. D. and Kapustin, V. N.: A pacific aerosol survey, Part 1: A decade of data on particle production, transport, evolution, and mixing in the troposphere, J. Atmos. Sci., 59, 363-382, 2002.
Davison, B., Nicholas Hewitt, C., O’Dowd, C. D., Lowe, J. A., Smith, M. H., Schwikowski, M., Baltensperger, U., and Harrison, R. M.: Dimethyl sulfide, methane sulfonic acid and physicochemical aerosol properties in Atlantic air from the United Kingdom to Halley Bay, J. Geophys. Res., 101(D17), 22 855-22 868, 1996.

Deshpande, C. G. and Kamra, A. K.: Physical properties of aerosols at Maitri, Antarctica, Proc. Indian Acad. Sci. (Earth Planet. Sci.), 113, 1-25, 2004.

Dhanorkar, S. and Kamra, A. K.: Diurnal variation of ionization rate close to ground, J. Geophys. Res., 99(D9), 18 523-18 526, doi:10.1029/94JD01335, 1994.

$\mathrm{Du}, \mathrm{H}$. and Yu, F.: Formation of volatile nanoparticles in engine exhaust: Contributions of the binary $\mathrm{H}_{2} \mathrm{SO}_{4}-\mathrm{H}_{2} \mathrm{O}$ homogeneous nucleation, Atmos. Environ., 40, 7579-7588, 2006.

Duncan, B. N., Martin, R. V., Staudt, A. C., Yevich, R., and Logan, J. A.: Interannual and seasonal variability of biomass burning emissions constrained by satellite observations, J. Geophys. Res., 108(D2), 4100, doi:10.1029/2002JD002378, 2003.

Dunn M. J., Jiménez, J.-L., Baumgardner, D., Castro, T., McMurry, P. H., Smith, J. N.: Measurements of Mexico City nanoparticle size distributions: Observations of new particle formation and growth, Geophys. Res. Lett., 31, L10102, doi:10.1029/2004GL019483, 2004.

Evans, M. J. and Jacob, D. J.: Impact of new laboratory studies of $\mathrm{N}_{2} \mathrm{O}_{5}$ hydrolysis on global model budgets of tropospheric nitrogen oxides, ozone, and OH, Geophys. Res. Lett., 32, L09813, doi:10.1029/2005GL022469, 2005.

Fairlie, T. D., Jacob, D. J., and Park, R.: A simulation of the transpacific transport of mineral dust from Asia during spring 2001: Evaluation of results from GEOS-CHEM with ground-based, aircraft and satellite measurements, Eos Trans. AGU, 85(17), Jt. Assem. Suppl., Abstract A31B-07, 2004.

Fan J., Zhang, R., Collins, D., Li, G.: Contribution of secondary condensable organics to new particle formation: A case study in Houston, Texas, Geophys. Res. Lett., 33, L15802, doi:10.1029/2006GL026295, 2006.

Ghan, S. J. and Schwartz, S. E.: Aerosol properties and processes: A path from field and laboratory measurements to global climate models, Bull. Amer. Meteorol. Soc., 88, 1059-1083, 2007.

Gong, Y., Hang, S., Fang, C., et al.: Analysis on concentration and source rate of precursor vapors participating in particle formation and growth at Xinken in Pearl River Delta of China, Advances in Atmospheric Sciences, 25(3), 427-436, 2008.

Grabarczyk, Z. J. and Berlinski, J.: Charging of atmosphere aerosols by AC HV power lines, J. Electrostatics, 63, 755-759, 2005.

Hamed, A., Joutsensaari, J., Mikkonen, S., et al.: Nucleation and growth of new particles in Po Valley, Itally, Atmos. Chem. Phys. Discuss., 6, 9603-9653, 2006, http://www.atmos-chem-phys-discuss.net/6/9603/2006/.

Hanson, D. R. and Lovejoy, E. R.: Measurement of the thermodynamics of the hydrated dimmer and trimer of sulfuric acid, J. Phys. Chem. A., 110, 9525-9528, doi:10.1021/jp062844w, 2006.

Heintzenberg, J., Hermann, M., and Theiss, D.: Out of Africa: High aerosol concentrations in the upper troposphere over Africa, Atmos. Chem. Phys., 3(4), 1191-1198, 2003.

Hirsikko, A., Bergman, T., Laakso, L., Dal Maso, M., Riipinen, I., Hõrrak, U. and Kulmala, M.: Identification and classification 
of the formation of intermediate ions measured in boreal forest, Atmos. Chem. Phys. 7, 201-210, 2007.

Hopke, P. H. and Utell, M. J.: Ambient Air Quality Monitoring of Ultrafine Particles in Rochester, New York - NYSERDA Report 05-04, 2005.

Iida, K., Stolzenburg, M., McMurry, P., Dunn, M. J., Smith, J. N., Eisele, F., and Keady, P.: Contribution of ion-induced nucleation to new particle formation: Methodology and its application to atmospheric observations in Boulder, Colorado, J. Geophys. Res., 111, D23201, doi:10.1029/2006JD007167, 2006.

IPCC, Climate Change 2007: The Physical Scientific Basis, edited by Solomon, S., Qin, D., Manning, M., Chen, Z., Marquis, M., Averyt, K. B., Tignor M., and Miller, H. L., Cambridge Univ. Press, New York, 2007.

Ito, T.: Size distribution of Antarctic submicron aerosols, Tellus, Ser. B, 45, 145-159, 1993.

Jeong, C. H., Evans, G. J., Hopke, P. H., Chalupa, D., Utell, M. J.: Influence of atmospheric dispersion and new particle formation events on ambient particle number concentration in Rochester, United States, and Toronto, Canada? J. Air and Waste Manage. Assoc., 56, 431-443, 2006.

Kazil, J., Lovejoy, E. R., Barth, M. C., and O'Brien, K.: Aerosol nucleation over oceans and the role of galactic cosmic rays, Atmos. Chem. Phys., 6, 4905-4924, 2006,

http://www.atmos-chem-phys.net/6/4905/2006/.

Koponen I. K., Virkkula, A., Hillamo, R., Kerminen, V.-M., and Kulmala, M.: Number size distributions and concentrations of marine aerosols: Observations during a cruise between the English Channel and the coast of Antarctica, J. Geophys. Res., 107(D24), 4753, doi:10.1029/2002JD002533, 2002.

Kulmala, M., Vehkamäki, H., Petäjä, T., Dal Maso, M., Lauri, A., Kerminen, V.-M., Birmili, W., and McMurry, P.: Formation and growth rates of ultrafine atmospheric particles: A review of observations, J. Aerosol Sci., 35, 143-176, 2004.

Kulmala, M., Riipinen, I., Sipilä, M., et al.: Toward direct measurement of atmospheric nucleation, Science, 318, 89-92, 2007.

Kulmala, M., Lehtinen, K. E. J., and Laaksonen, A.: Cluster activation theory as an explanation of the linear dependence between formation rate of $3 \mathrm{~nm}$ particles and sulphuric acid concentration, Atmos. Chem. Phys., 6, 787-793, 2006, http://www.atmos-chem-phys.net/6/787/2006/.

Laakso, L., Gagné, S., Petäjä, T., Hirsikko, A., Aalto, P. P., Kulmala, M., and Kerminen, V.-M.: Detecting charging state of ultra-fine particles: instrumental development and ambient measurements, Atmos. Chem. Phys. 7, 1333-1345, 2007.

Laakso, L., Anttila, T., Lehtinen, K. E. J., Aalto, P. P., Kulmala, M., Hõrrak, U., Paatero, J., Hanke, M., and Arnold, F.: Kinetic nucleation and ions in boreal forest particle formation events, Atm. Chem. Phys., 4, 2353-2366, 2004.

Laaksonen, A., Hamed, A., Joutsensaari, J., Hiltunen, L., Cavalli, F., Junkermann, W., Asmi, A., Fuzzi, S., and Facchini, M. C.: Cloud condensation nucleus production from nucleation events at a highly polluted region, Geophys. Res. Lett., 32, L06812, doi:10.1029/2004GL022092, 2005.

Lee, Y.-G., Choi, C.-H., and Choi, B.-C.: Characterization of particle growth events at western coastal site of Korea in 2005, in Proceedings of 7th International Aerosol Conference, 1220-1221, 2006.

Lihavainen, H., Panwar, T. S., Komppula, M., et al.: Aerosol prop- erties in background site in India, in Proceedings of 7th International Aerosol Conference, 1226, 2006.

Liss, P. S., and Merlivat, L.: Air-sea gas exchange rates: Introduction and synthesis, in The Role of Air-Sea Exchange in Geochemical Cycling, edited by Buat-Me'nard, P., D. Reidel, 113127, Norwell, Mass, 1986.

Lovejoy, E. R., Curtius, J., and Froyd, K. D: Atmospheric ioninduced nucleation of sulfuric acid and water, J. Geophys. Res., 109, D08204, doi:10.1029/2003JD004460, 2004.

Lucas, D. D., and Akimoto, H.: Evaluating aerosol nucleation parameterizations in a global atmospheric model. Geophys. Res. Lett., 33, L10808, doi:10.1029/2006GL025672, 2006.

Martin, R. V., Jacob, D. J., Yantosca, R. M., Chin, M., and Ginoux, P.: Global and regional decreases in tropospheric oxidants from photochemical effects of aerosols, J. Geophys. Res., 108, 4097, doi:10.1029/2002JD002622, 2003.

McMurry, P. H., et al.: A criterion for new particle formation in the sulfur-rich Atlanta atmosphere, J. Geophys. Res., 110, D22S02, doi:10.1029/2005JD005901, 2005.

Modgil, M. S., Kumar, S., Tripathi, S. N., and Lovejoy, E. R.: A parameterization of ion-induced nucleation of sulphuric acid and water for atmospheric conditions, J. Geophys. Res., 110, D19205, doi:10.1029/2004JD005475, 2005.

Mozurkewich, M., Chan, T.-W., Aklilu, Y.-A., and Verheggen, B.: Aerosol particle size distributions in the lower Fraser Valley: evidence for particle nucleation and growth, Atmos. Chem. Phys., 4, 1047-1062, 2004, http://www.atmos-chem-phys.net/4/1047/2004/.

Napari, I., Noppel, M., Vehkamäki, H., and Kulmala, M.: Parametrization of ternary nucleation rates for $\mathrm{H}_{2} \mathrm{SO}_{4}$ $\mathrm{NH}_{3}-\mathrm{H}_{2} \mathrm{O}$ vapors, J. Geophys. Res., 107(D19), 4381, doi:10.1029/2002JD002132, 2002.

Nenes, A., Pandis, S. N., and Pilinis, C.: ISORROPIA: A new thermodynamic equilibrium model for multiphase multicomponent inorganic aerosols, Aquatic Geochemistry, 4, 123-152, 1998.

NRC, Radiative Forcing of Climate Change: Expanding the Concept and Addressing Uncertainties, National Academies Press, 2005.

O’Dowd, C. D.,Geever, M., Hill, M. K., Smith, M. H., Jennings, S. G.: New particle formation: Nucleation rates and spatial scales in the clean marine coastal environment, Geophys. Res. Lett., 25(10), 1661-1664, doi:10.1029/98GL01005, 1998.

O’Dowd, C. D., Jimenez, J. L., Bahreini, R., et al.: Marine aerosol formation from biogenic iodine emissions, Nature, 417, 632636, 2002.

Olivier, J. G. J., Berdowski, J. J. M., Peters, J. A. H. W., Bakker, J., Visschedijk en, A. J. H., and Bloos J.-P. J.: Applications of EDGAR, Including a description of EDGAR 3.0: reference database with trend data for 1970-1995. RIVM, Bilthoven. RIVM report no. 773301 001/ NOP report no. 410200 051, 2001.

Park, R. J., Jacob, D. J., Field, B. D., Yantosca, R. M., and Chin, M.: Natural and transboundary pollution influences on sulfate-nitrate-ammonium aerosols in the United States: Implications for policy, J. Geophys. Res., 109, D15204, doi:10.1029/2003JD004473, 2004.

Park, R. J., Jacob, D. J., Chin, M., and Martin, R. V.: Sources of carbonaceous aerosols over the United States and implications for natural visibility, J. Geophys. Res., 108, 4355, doi:10.1029/2002JD003190, 2003. 
Petäjä, T., Kerminen, V.-M., Dal Maso, M., et al.: Sub-micron atmospheric aerosols in the surroundings of Marseille and Athens: physical characterization and new particle formation, Atmos. Chem. Phys., 7, 2705-2720, 2007,

http://www.atmos-chem-phys.net/7/2705/2007/.

Pierce, J. R. and Adams, P. J: Efficiency of cloud condensation nuclei formation from ultrafine particles, Atmos. Chem. Phys., 7, 1367-1379, 2007, http://www.atmos-chem-phys.net/7/1367/2007/.

Qian, S., Sakurai, H., and, McMurry, P. H.: Characteristics of regional nucleation events in urban East St. Louis, Atmospheric Environment, 41, 4119-4127, 2007.

Reiter, R.: Phenomena in Atmospheric and Environmental Electricity, Elsevier, New York, 1992.

Spracklen, D. V., Carslaw, K. S., Kulmala, M., Kerminen, V.-M., Mann, G. W., Sihto, S.-L.: The contribution of boundary layer nucleation events to total particle concentrations on regional and global scales, Atmospheric Chemistry and Physics, 6(12), 56315648, 2006.

Stanier, C., Khlystov, A., and Pandis, S. N.: Nucleation events during the Pittsburgh Air Quality Study: Description and relation to key meteorological, gas phase, and aerosol parameters, Aerosol Sci. Technol., 38, suppl. 1, 253-264, 2004.

Suda, T. and Sunaga, Y.: An experimental study of large ion density under the Shiobara HVDC test line, IEEE Trans Power Delivery, 5, 1426-1435, 1990.

Suni, T., Gorsel, E. V., Cleugh, H., et al.: Biogenic Aerosol Formation in a Native Australian Eucalypt Forest, in Proceedings of 7th International Aerosol Conference, p. 1241, 2006.

Turco, R. P., Zhao, J. X., and Yu, F.: A new source of tropospheric aerosols: Ion-ion recombination, Geophys. Res. Lett., 25, 635638, 1998.

Twomey, S.: The influence of pollution on the shortwave albedo of clouds, J. Atmos. Sci., 34, 1149-1152, 1977.

Usoskin I. G., and Kovaltsov, G. A.: Cosmic ray induced ionization in the atmosphere: Full modeling and practical applications, J. Geophys. Res., 111, D21206, doi:10.1029/2006JD007150, 2006.

Vartiainen, E., Kulmala, M., Ehn, M., et al.: Ion and particle number concentrations and size distributions along the Trans-Siberrian railroad, Boreal Env. Res., 12, 375-396, 2007.

Vehkamäki, H., Kulmala, M., Napari, I., Lehtinen, K. E. J., Timmreck, C., Noppel, M., and Laaksonen, A.: An improved parameterization for sulfuric acid-water nucleation rates for tropospheric and stratospheric conditions, J. Geophys. Res., 107(D22), 4622, doi:10.1029/2002JD002184, 2002.
Vehkamäki, H., Dal Maso, M., Hussein, T., et al.: Atmospheric particle formation events at Värriö measurement station in Finnish Lapland 1998-2002, Atmos. Chem. Phys., 4, 2015-2023, 2004, http://www.atmos-chem-phys.net/4/2015/2004/.

Weber, R. J., Lee, S., Chen, G., et al.: New particle formation in anthropogenic plumes advecting from Asia observed during TRACE-P, J. Geophys. Res., 108(D21), 8814, doi:10.1029/2002JD003112, 2003.

Wehner, B., Bauer, S., Wu, Z., et al.: Formation and Growth of Ultrafine Particles in Beijing, China, in Proceedings of 7th International Aerosol Conference, 1609-1610, 2006.

Wu, Z., Hu, M., Liu, S., Wehner, B., Bauer, S., Maßling, A., Wiedensohler, A., Petäjä, T., Dal Maso, M., Kulmala, M.: New particle formation in Beijing, China: Statistical analysis of a 1-year data set, J. Geophys. Res., 112, D09209, doi:10.1029/2006JD007406, 2007.

Yevich, R. and Logan, J. A.: An assessment of biofuel use and burning of agricultural waste in the developing world, Global Biogeochem. Cycles, 17(4), 1095, doi:10.1029/2002GB001952, 2003.

Yu, F.: From molecular clusters to nanoparticles: Secondgeneration ion-mediated nucleation model, Atmos. Chem. Phys., 6, 5193-5211, 2006a, http://www.atmos-chem-phys.net/6/5193/2006/.

$\mathrm{Yu}, \mathrm{F}$. : Binary H2SO4-H2O homogeneous nucleation rates based on a kinetic quasi-unary model: Look-up tables, J. Geophy. Res., 111, D04201, doi:10.1029/2005JD006358, 2006b.

$\mathrm{Yu}, \mathrm{F}$.: Improved quasi-unary nucleation model for binary $\mathrm{H}_{2} \mathrm{SO}_{4}-$ $\mathrm{H}_{2} \mathrm{O}$ homogeneous nucleation, J. Chem. Phys., 127, 054301, 2007.

Yu, F. and Turco, R. P.: Charged State of Freshly Nucleated Particles: Implications for Nucleation Mechanisms, in Proceeding of 17th International Conference on Nucleation \& Atmospheric Aerosols, Galway, Ireland, 13-17 August 2007.

Yu, F. and Turco, R. P.: Case studies of particle formation events observed in boreal forests: Implications for nucleation mechanisms, Atmos. Chem. Phys. Discuss., 8, 5683-5723, 2008, http://www.atmos-chem-phys-discuss.net/8/5683/2008/.

Yum, S. S., Roberts, G., Kim, J. H., Song K., and Kim, D.: Submicron aerosol size distributions and cloud condensation nuclei concentrations measured in JejuDo, Korea during the ABCEAREX 2005, in Proceedings of 7th International Aerosol Conference, $\mathrm{p}$ 1158, 2006 